\title{
Determinants of Option Markets Liquidity: An Empirical Analysis on European Markets
}

\author{
Thomas Poufinas $^{1^{*}}\left(\mathbb{D}\right.$, Konstantinos Pappas $^{2}$ \\ ${ }^{1}$ Department of Economics, Democritus University of Thrace, Komotini, Greece \\ ${ }^{2}$ Graduate Program in Business Mathematics, University of Athens and Athens University of Economics and Business, Athens, Greece \\ Email: *tpoufina@econ.duth.gr, konstantinospapppas@gmail.com
}

How to cite this paper: Poufinas, T., \& Pappas, K. (2021). Determinants of Option Markets Liquidity: An Empirical Analysis on European Markets. Theoretical Economics Letters, 11, 824-857. https://doi.org/10.4236/tel.2021.114053

Received: July 8, 2021

Accepted: August 28, 2021

Published: August 31, 2021

Copyright (c) 2021 by author(s) and Scientific Research Publishing Inc. This work is licensed under the Creative Commons Attribution International License (CC BY 4.0).

http://creativecommons.org/licenses/by/4.0/

(c) (i) Open Access

\begin{abstract}
This paper attempts to discover the macroeconomic determinants of liquidity in option markets, which is measured by the open interest, the volume (number of transactions), the implied volatility and the bid-ask spread. The macroeconomic determinants of each European economy employed in this study are 1) the gross domestic product, the gross domestic product per capita, the unemployment rate, the income tax rate, the corporate tax rate, the population, the bank capital-to-assets ratio, the inflation, the 10-year government bond yield rate, 2) the market capitalization (of listed domestic companies), the Standard \& Poor's global equity indices (annual \% change), the stocks traded (turnover ratio of domestic shares (\%) and total value), which show the breadth of a country's capital markets, as well as 3 ) indices like the economic freedom, the freedom from corruption, the fiscal freedom, the business freedom, the investment freedom, the financial freedom. Panel data linear regressions are performed to find evidence that the liquidity of the option markets is mainly affected by macroeconomic and capital market determinants, whereas the economic freedom indicators play a less significant role. The findings can be of use to the policymakers and option market authorities who wish to increase the liquidity of these markets. The novelties introduced by this study are the consideration of macroeconomic variables as determinants of option market liquidity and the subsequent use of these determinants in order to make policy recommendations.
\end{abstract}

\section{Keywords}

Options, Liquidity, Open Interest, Volume, Bid-Ask Spread, Implied Volatility

\section{Introduction}

The intuition behind this research stems from the input of officers of derivatives 
exchanges and market participants who faced decreased liquidity in certain exchanges, especially during or after the financial crisis. This was more apparent in distressed countries, especially the ones that had to rely on support mechanisms in the European South, with the most prominent example being Greece. The interested parties realized that the authorities most likely had to take action in order to increase liquidity and they needed some answers in terms of whether it was solely an issue of the derivatives exchange authorities or the policymakers of the country as a whole. Consequently, investigating the impact of macroeconomic metrics, (equity) market characteristics, as well as perceived economic freedom to the liquidity of the derivatives market offers potential answers and paves the path for potential measures that if implemented, could assist in overcoming the exhibited illiquidity. As option markets have been in the spotlight this study investigates the determinants of their liquidity.

But why is there an interest in liquidity? Obviously there are many reasons for that. Starting with investors, it is clear that they cherish liquidity because it enhances the value of their assets. The ability to sell an asset without a large price change or impact enhances its attractiveness as a store of value. For the most part, this leads to a concern about average market liquidity, which varies greatly across asset classes even in normal market regimes. The global financial crisis highlighted the importance that liquidity has and its central role in well-functioning financial markets. Failure to adequately assess and manage liquidity underpinned major market turmoil, triggered unprecedented liquidity events and the ultimate demise of financial institutions such as Bear Stearns, Lehman Brothers that were previously thought too big to fail.

Liquidity is generally described as the ability to enter and exit in a trade easily thus encompassing a time, price and volume component. To identify liquidity in option markets professionals and researchers look at 4 option metrics; namely volume, open interest, bid-ask spread and implied volatility.

The problem many stock exchange policy makers face is the understanding of the full spectrum of factors that impact the liquidity of their option products and the option market sensitivity to various exogenous macroeconomic factors. The lack of clearly defined option liquidity factors used among professionals and the limited research being contacted about liquidity characteristics of option markets (as opposed to the extensive research on stock market liquidity) have deemed the policy making process of an option exchange a difficult endeavor.

Summing up, the contextual insight offered by the previous background is that liquidity is important for the investors, the intermediaries and the derivatives exchanges as it allows for more products (e.g. options with more strike prices and maturity dates), optimal pricing, easier trading (even block-trading), more efficient hedging and even speculation opportunities. Moreover, it allows for higher commissions due to higher volumes and not due to higher bid-ask spreads. In addition, it seems that both the market and the academia have agreed to the most relevant liquidity proxies, which are volume, open interest, bid-ask 
spread and implied volatility. What has not been investigated though is what drives these measures of liquidity.

It is therefore a valid research question to ask what the determinants of the option market liquidity are and what the stakeholders can do to increase it. The objective of this paper is to uncover the links between various macroeconomic factors and proxies of option liquidity metrics, especially examining the option markets of 15 European countries; thus, providing a framework for policy decision making regarding the facilitation of liquidity in option markets. Consequently, the novelties of this paper are identified in 1) the empirical assessment of the effect of macroeconomic indicators on option market liquidity with emphasis on exogenous factors that lie beyond the underlying market (of course, all factors that have been previously used in different studies are incorporated); 2) the incorporation of a greater number of proxies for liquidity compared to the existing research in the field; and 3) the identification of a series of directions that the policy makers can follow in order to increase the option market liquidity.

The remainder of this paper is organized as follows. Section 2 provides a brief review of the published literature. Section 3 sets the theoretical background of the problem. Section 4 describes the methods, approaches and data used. Section 5 presents our regression findings. Section 6 discusses our results and Section 7 the implications. Further research venues are recommended in Section 8, whereas Section 9 concludes our research.

\section{Literature Review}

The academic research in the area of financial product liquidity is extensive and whereas the derivative markets have been a subject of interest of numerous studies the current literature has not yet presented a satisfactory number of research papers on the liquidity of option markets. The majority of option liquidity research attempts to establish the relation of underlying market and option liquidity and focus on option market characteristics that shape liquidity. They do not address the macroeconomic variables or the economic freedom indicators that the present study employs.

Starting with its definition, as mentioned in the introduction liquidity is captured by the ability to enter and exit in a trade easily thus incorporating time, price and volume. This ability is translated and priced as cost which is measured as the mark down of a fire sale of a contract by an urgent seller. According to Shah et al. (2009), on average, a markdown equals to half of the bid-ask spread. Since brokerage commissions do not vary with the time taken to complete a transaction, differences in bid-ask spread indicate differences in the liquidity cost (Demsestz, 1968). To identify liquidity in option markets professionals and researchers look at volume, open interest, bid-ask spread and implied volatility.

Liquid and heavily traded option contracts tend to have more strike prices, expiration dates, whereas bull and bear spreads, straddles and other strategies 
are offered, involving one or more contracts. Furthermore, a busy market with many participants typically has narrower spreads between the bid prices and the ask prices According to TD Ameritrade (2015), quoting a study by Henry Schwartz at Trade Alert, the top 132 most active names, or 3\% of listed options, see roughly $80 \%$ of total trading volume. In other words, the bottom $97 \%$ sees only $20 \%$ of the options volume. Clearly, the deeper liquidity pools are concentrated in a handful of names in the options market these days.

Mayhew et al. (1999) examined how the daily order flow in options is related to the characteristics of the underlying stock suggesting that option liquidity is positively correlated with stock price volatility and trading volume.

Kalodera and Schlag (2004) suggested that frequency and volume of option trades is positively correlated with stock volume based on their findings studying the German option market.

Capelle (2001) examined implied volatility and its implications on option market liquidity taking into account the volatility trades that take part in such markets. He proposes that for an optimal strategy in option markets you have to account for the percentage of liquidity traders and volatility traders. Consequently, bid and ask prices and thus liquidity in two different markets are functions of these percentages.

Cao and Wei (2010) discovered that commonality for various liquidity measures is strong, while information asymmetry influences liquidity in option markets more than inventory risk and suggested that the option liquidity is linked to the underlying stock market's movements.

Wei and Zheng (2010) empirically examine the impact of trading activities on the liquidity of individual equity options as measured by the proportional bid-ask spread to find that (a) the option return volatility has a much higher explanatory power in explaining the spread variations compared with the stock return volatility and the option trading volume; (b) after controlling for the endogenous liquidity determinants (measures) there is a maturity substitution effect; and (c) there is a moneyness substitution effect induced by the stock return volatility.

Battalio and Schultz (2011) find that regulatory restrictions, such as the short sale ban, produce uncertainty that can impact the option market liquidity, as they lead to significantly increased bid-ask spreads for options on the banned stocks.

Chaudhury (2015) searches for quantitative measures of option liquidity. He shows that the relative spread measure, defined as bid-ask spread over the mid-price, does not rank options in terms of their liquidity in line with the popular view and leads to a bias against lower-prices options. He therefore recommends two alternative measures of option liquidity; namely the implied volatility of the underlying asset and the bid, ask and mid option prices in terms of implied volatility. By employing these liquidity measures he produces a ranking of options in terms of their liquidity that seems to be more in line with the common knowledge.

Gueant (2016), and Guéant and Pu (2017) look at liquidity from two angles: 
(a) the type of orders Gueant (2016) and (b) the optimal execution of orders Guéant and $\mathrm{Pu}$ (2017). More specifically they investigate (a) different types of orders that can achieve optimal liquidation Gueant (2016) and (b) Guéant and $\mathrm{Pu}$ (2017) how the models that are available for the optimal execution of orders can be used to price and hedge equity derivatives. For the former they utilize the Almgren-Chriss framework to deal with different types of orders, such as Target Close, Percent of Volume (POV) and Volume-Weighted Average Price (VWAP) orders. For the latter they employ this model to rather generalize the classical option pricing models by introducing execution costs and permanent market impact. The Almgren-Chriss framework models the optimal pace to build or unwind a position, i.e. to schedule the execution.

Bernales et al. (2018) find evidence that there is a liquidity searching behavior of informed investors in option listings and that the option bid-ask spread may still be a good proxy for informed trading besides this liquidity searching behavior. They show that there is an upward trend in the bid-ask spread of options after option introductions. This is most likely attributed to the fact that informed traders avoid trading in initial periods after listing dates due to low liquidity exhibited.

In summary, the present research is more in line with the studies of Mayhew et al. (1999), Kalodera and Schlag (2004), Capelle (2001) and Cao and Wei (2010), in the sense that it employs primarily the measures that they find to be good proxies of option price liquidity. However, it focuses on finding exogenous measures/determinants of option market liquidity and not endogenous as they did. The work of Wei and Zheng (2010) is not in the same wavelength with this study and that of the previous authors as they investigate an alternative liquidity measure that the present approach does not use. It however verifies the importance of the traditional liquidity measures, which are considered in this paper. The same pretty much holds true for the findings of Battalio and Schultz (2011). Chaudhury introduces variations of the option liquidity measures, which are not used in the present approach either, as it focuses on the traditional ones, thus following a different route. The direction of Gueant (2016), and Guéant and Pu (2017) is also different as they are not really addressing the determinants of option market liquidity, but rather investigate the impact of liquidity in order execution. The work of Bernales et al. (2018) also diverts from this paper; it however signifies the importance of liquidity and moreover verifies the use of bid-ask spread as a good proxy for liquidity. Consequently, the work deployed in this manuscript adds to the existing literature as it examines the option price liquidity from a new perspective; that of its dependence from a series of macroeconomic determinants of an economy, of market related factors and of economic freedom indices. In addition, as stressed earlier, it employs a bigger number of proxies and drafts directions that policymakers can follow in order to increase the option market liquidity. These points summarize the novelties introduced through this paper. 


\section{Problem Description and Theoretical Background}

The intuition behind the topic of liquidity of option markets is the need of the derivatives exchanges to secure a level of liquidity that makes sense for the investors, the issuers as well as the exchange itself. Low liquidity makes the participation expensive and unreliable for the investors and results in a reduced interest. The latter discourages the participation of the issuers as well as of the derivatives exchange. An example is the Athens Stock Exchange, which has experienced an extremely thin trading as a result of the financial crisis that hit the Greek economy the most.

The question that the stock exchanges try to answer is what are the determinants of the liquidity of the option markets? To answer this question, one needs to agree first on the measures of liquidity. The obvious one is the volume of the options traded, as per Kalodera and Schlag (2004), Cherian (1999), as well as the open interest, as per Donders et al. (2000). The bid-ask spread tends to be high in illiquid markets; hence it is also considered a measure of liquidity (Cberian \& Vila, 1997); Mayhew et al. (1999). Finally, the implied volatility also tends to be high in thinly traded markets, which makes it also a liquidity metric (Capelle, 2001; Cberian \& Vila, 1997).

Most of the recent literature tackles the pricing of the (il)liquidity cost (Shah and Brorsen (2013). However, the interest of the derivatives exchanges is how to increase the liquidity and not to estimate its cost. In this respect, there are several directions that can be followed to find the determinants of the liquidity. One is to examine, the effect of certain variables related to the country. These are the macroeconomic figures, the capital market figures and the economic freedom indicators of each country of interest. The other, would be to consider the opinion of the market; i.e. contact market researches to the countries of interest that will map the consensus as of the level of fees that would be satisfactory for the intermediaries and acceptable by the investors as well as the additional steps that need to be taken by the responsible institutions, so that the liquidity increases.

In this research the first route is followed; i.e. the link between the option market liquidity as measured by volume, open interest, bid-ask spread and implied volatility with the variables that determine it is analyzed, as presented in the abstract and in section 5 below. Revealing this relationship can be helpful for the derivative exchanges and in particular the policy makers, as they can decide what country figures they need to improve so as to increase the liquidity of the derivative exchanges. Especially in a post-crisis era, the lack of liquidity is more structural and related to the country rather than the exchange itself. Countries that have been hit the most by the crisis are expected to experience lower liquidity in their options markets compared to the countries that weathered the crisis more successfully. Hence, tackling it requires a global approach rather than an instrument (derivative) specific approach. 


\section{Data, Variables and Methodology}

\subsection{Data}

Our dataset is comprised by volume, ask, bid, implied volatility and open interest values on call and put options on stock market representative indexes (DataStream, 2017), by country macroeconomic factors (World Bank Open Data, 2017) and by economic freedom indices (The Heritage Foundation, 2012-2016). The macroeconomic factors dataset is comprised of bank capital to assets ratio, gross domestic product (GDP), GDP per capita, inflation, interest rates (10-year government bond yield), population, public debt (as a \% of GDP), unemployment rate, income tax rate, corporate tax rate and foreign direct investments (FDI). The economic freedom indices consist of economic freedom, freedom from corruption, fiscal freedom, business freedom, investment freedom and financial freedom. Our sample contains options on indices from Austria, Belgium, Denmark, Finland, France, Germany, Greece, Italy, Netherlands, Norway, Spain, Sweden, Switzerland and the United Kingdom (UK) (Table 1). All option related values are collected from the Thomson Reuters database (DataStream, 2017).

The various liquidity metrics exhibit a wide range of values (Table 2). The bid and ask values are not immediately comparable as they depend on the underlying index level; hence no further comments are made on them. Spain exhibits the smallest implied volatility average and standard deviation, whereas Germany has the biggest implied volatility, again both average and standard deviation. Germany has the biggest volume, whereas Belgium has the smallest volume-in terms of average and standard deviation. France shows the biggest open interest in terms of average and Germany in terms of standard deviation, whereas Austria shows the smallest open interest both in terms of average and standard deviation.

Table 1. Countries and Stock exchange indexes.

\begin{tabular}{lccc}
\hline Country & Index & County & Index \\
\hline Austria & ATX index & Netherlands & AEX-Euronext index \\
Belgium & BEL 20 Euronext index & Norway & OBX Index \\
Denmark & OMX Copenhagen 20 index & Spain & IBEX35 index \\
Finland & OMX Helsinki 25 index & Sweden & OMX Stockholm 30 index \\
France & CAC 40 Euronext index & Switzerland & SMI index \\
Germany & DAX index & United Kingdom & FTSE 100 Index \\
Greece & FTSE/Athex Large Cap index & Sweden, Finland, & NASDAQ Nordic index \\
Italy & FTSE MIB index & & \\
\hline
\end{tabular}

Source: created by the authors with input from Datastream (2017) on the stock market representative indexes by country. 
Table 2. Descriptive statistics by country and liquidity measure.

\begin{tabular}{|c|c|c|c|c|c|c|c|c|c|c|c|}
\hline \multicolumn{2}{|c|}{ Austria: ATX } & MAX & MIN & AVG & ST.DEV & \multicolumn{2}{|c|}{ Spain IBEI } & MAX & MIN & AVG & ST.DEV \\
\hline \multirow{2}{*}{ ASK } & Calls & 507,00 & 1,59 & 107,31 & 39,62 & \multirow{2}{*}{ ASK } & Calls & $9.211,00$ & 1,00 & 258,83 & 278,57 \\
\hline & Puts & 342,00 & 1,40 & 92,78 & 29,72 & & Puts & $3.000,00$ & 1,00 & 237,57 & 300,27 \\
\hline \multirow{2}{*}{ BID } & Calls & 466,00 & 143,00 & 107,00 & 43,49 & \multirow{2}{*}{ BID } & Calls & $2.750,00$ & 1,00 & 226,82 & 223,09 \\
\hline & Puts & 292,00 & 16,80 & 71,39 & 27,54 & & Puts & $2.236,00$ & 1,00 & 195,21 & 255,76 \\
\hline IMP. VOLATILITY & Calls \& Puts & 2,71 & 0,01 & 0,57 & 0,35 & IMP. VOLATILITY & Calls \& Puts & 7,04 & 0,00 & 0,10 & 0,05 \\
\hline VOLUME & Calls \& Puts & $5.856,00$ & 0,00 & $1.081,68$ & $1.431,73$ & VOLUME & Calls \& Puts & $1.216 .073,00$ & 0,00 & $38.888,50$ & $71.014,09$ \\
\hline OPEN INTERSEST & Calls \& Puts & 663,00 & 0,00 & 25,16 & 62,38 & OPEN INTERSEST & Calls \& Puts & $2.452 .308,00$ & 0,00 & $1.421 .199,19$ & 9,97 \\
\hline \multicolumn{2}{|c|}{ UK ESX } & MAX & MIN & AVG & ST.DEV & \multicolumn{2}{|c|}{ Brussels BBEL } & MAX & MIN & AVG & ST.DEV \\
\hline ASK & Puts & $4.283,80$ & 0,10 & 158,75 & 50,38 & ASK & Puts & $1.250,00$ & 0,04 & 79,96 & 49,75 \\
\hline \multirow{2}{*}{ BID } & Calls & $3.861,25$ & 0,70 & 126,52 & 73,86 & \multirow{2}{*}{ BID } & Calls & $1.113,00$ & 0,01 & 54,47 & 39,01 \\
\hline & Puts & $33.497,00$ & 0,00 & 638,29 & 57,46 & & Puts & $1.404,50$ & 0,01 & 75,85 & 51,78 \\
\hline IMP. VOLATILITY & Calls \& Puts & 9,14 & 0,00 & 0,20 & 0,04 & IMP. VOLATILITY & Calls \& Puts & 7,07 & 0,00 & 0,24 & 0,08 \\
\hline VOLUME & Calls \& Puts & $99.372,00$ & 0,00 & $11.894,39$ & $12.954,80$ & VOLUME & Calls \& Puts & 728,00 & 0,00 & 6,62 & 25,26 \\
\hline OPEN INTERSEST & Calls \& Puts & $10.108 .194,00$ & $10.978,00$ & $6.478 .809,39$ & $1.440 .817,14$ & OPEN INTERSEST & Calls \& Puts & 470,00 & 6,00 & 112,28 & 96,51 \\
\hline \multicolumn{2}{|c|}{ France PXA } & MAX & MIN & AVG & ST.DEV & \multicolumn{2}{|c|}{ Netherlands EOE } & MAX & MIN & AVG & ST.DEV \\
\hline ASK & Calls & $4.283,80$ & 0,10 & 158,75 & 50,38 & ASK & Calls & 500,00 & 0,01 & 50,62 & 5,94 \\
\hline BID & Puts & $4.067,20$ & 0,10 & 166,78 & 50,99 & BID & Puts & 389,80 & 0,10 & 136,19 & 36,38 \\
\hline IMP. VOLATILITY & Calls \& Puts & 9,52 & 0,00 & 0,71 & 0,80 & IMP. VOLATILITY & Calls \& Puts & 4,56 & 0,00 & 0,25 & 0,06 \\
\hline VOLUME & Calls \& Puts & $117.166,00$ & 0,00 & $28.810,85$ & $17.192,31$ & VOLUME & Calls \& Puts & $117.166,00$ & 0,00 & $28.810,85$ & $17.192,31$ \\
\hline OPEN INTERSEST & Calls \& Puts & $14.838 .299,00$ & $9.258 .612,00$ & $12.512 .227,61$ & $1.596 .257,14$ & OPEN INTERSEST & Calls \& Puts & $1.111 .098,00$ & $58.038,00$ & $663.134,63$ & $208.438,20$ \\
\hline \multicolumn{2}{|c|}{ Italy SMIB } & MAX & MIN & AVG & ST.DEV & Norway & OBX & MAX & MIN & AVG & ST.DEV \\
\hline ASK & Calls & $22.030,00$ & 0,03 & $1.469,38$ & $1.452,06$ & ASK & Calls & 232,50 & 0,01 & 42,44 & 11,66 \\
\hline ADK & Puts & $22.390,00$ & 0,03 & $1.354,22$ & $1.248,81$ & ASK & Puts & 272,00 & 0,01 & 31,35 & 11,44 \\
\hline BID & Calls & $21.930,00$ & 0,00 & $1.437,08$ & $1.513,89$ & BID & Calls & 268,25 & 0,01 & 36,89 & 9,26 \\
\hline Biv & Puts & $21.940,00$ & 0,00 & $1.265,55$ & $1.246,33$ & 1810 & Puts & 237,25 & 0,01 & 31,34 & 11,16 \\
\hline IMP. VOLATILITY & Calls \& Puts & 9,93 & 0,01 & 0,39 & 0,06 & IMP. VOLATILITY & Calls \& Puts & 9,03 & 0,03 & 0,24 & 0,06 \\
\hline VOLUME & Calls \& Puts & $30.723,00$ & 0,00 & 736,73 & $2.258,29$ & VOLUME & Calls \& Puts & $55.188,00$ & 0,00 & $6.105,95$ & $5.767,87$ \\
\hline OPEN INTERSEST & Calls \& Puts & $1.390 .818,00$ & $188.518,00$ & $752.384,10$ & $212.028,06$ & OPEN INTERSEST & Calls \& Puts & $266.070,00$ & $33.340,00$ & $129.361,00$ & $42.472,66$ \\
\hline Switzerla & d OSLI & MAX & MIN & AVG & ST.DEV & German & DAX & MAX & MIN & AVG & ST.DEV \\
\hline ASK & Calls & 236,30 & 0,70 & 31,62 & 17,77 & ASK & Calls & $99.999,00$ & 0,10 & 712,57 & 300,93 \\
\hline & Puts & 693,20 & 0,20 & 44,28 & 32,35 & & Puts & $12.345,00$ & 0,10 & 486,85 & 224,00 \\
\hline BID & Calls & 299,00 & 0,10 & 30,72 & 27,49 & BID & Calls & $12.045,00$ & 0,10 & 736,88 & 275,35 \\
\hline DID & Puts & 157,00 & 0,10 & 34,86 & 9,10 & DID & Puts & $8.767,40$ & 0,10 & 488,26 & 212,84 \\
\hline OPEN INTERSEST & Calls \& Puts & $38.785,00$ & $1.505,00$ & $10.263,28$ & $8.515,66$ & OPEN INTERSEST & Calls \& Puts & $13.396 .439,00$ & $1.605,00$ & $6.745 .055,08$ & $2.551 .623,68$ \\
\hline Nasdaq No & ic KC20 & MAX & MIN & \begin{tabular}{l|}
$A V G$ \\
\end{tabular} & ST.DEV & Nasdaq Nor & dic OS30 & MAX & MIN & \begin{tabular}{|c|} 
AVG \\
\end{tabular} & ST.DEV \\
\hline ASK & Calls & 370,25 & 0,01 & 27,36 & 15,29 & ASK & Calls & 876,00 & 0,01 & 47,31 & 19,95 \\
\hline 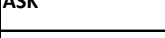 & Puts & 421,00 & 0,01 & 25,49 & 16,81 & ASK & Puts & 895,00 & 0,01 & 48,91 & 24,42 \\
\hline BID & Calls & 281,50 & 0,01 & 26,74 & 18,21 & BID & Calls & 820,50 & 0,01 & 57,55 & 28,90 \\
\hline & Puts & 281,50 & 0,01 & 24,25 & 15,41 & & Puts & 642,00 & 0,01 & 40,27 & 19,95 \\
\hline IMP. VOLATILITY & Calls \& Puts & 4,13 & 0,01 & 0,18 & 0,05 & IMP. VOLATILITY & Calls \& Puts & 7,37 & 0,01 & 0,23 & 0,06 \\
\hline VOLUME & Calls \& Puts & $6.642,00$ & 0,00 & 256,69 & 478,09 & VOLUME & Calls \& Puts & $2.508 .040,00$ & 0,00 & 13,91 & 34,78 \\
\hline OPEN INTERSEST & Calls \& Puts & $30.318,00$ & 0,00 & $7.236,25$ & $6.689,82$ & OPEN INTERSEST & Calls \& Puts & $2.504 .176,00$ & $337.076,00$ & \begin{tabular}{|l|}
$1.419 .582,36$ \\
\end{tabular} & $324.033,19$ \\
\hline
\end{tabular}

Source: created by the authors with input from Datastream (2017).

\subsection{Variables}

The variables that measure the liquidity in the option markets have been chosen as per the aforementioned literature review. The proxies for liquidity factors used as dependent variables are Volume, Open Interest, Implied Volatility and Bid-Ask Spread. The GDP, the GDP per capita, the unemployment rate, the income tax rate, the corporate tax rate, the population, the bank capital-to-assets ratio, the inflation, the 10-year government bond yield rate, the market capitalization (of listed domestic companies), the Standard \& Poor's (S\&P) global equity indices (annual \% change), the stocks traded (turnover ratio of domestic shares (\%) and total value), the economic freedom, the freedom from corruption, the fiscal freedom, the business freedom, the investment freedom and the financial freedom are used as explanatory variables. 


\subsection{Methodology}

In order to discover which macroeconomic factors, influence the liquidity in option markets, options on the most representative indexes of the national European stock markets were used as proxies of European option markets. The option metrics that according to literature act as liquidity indicators were regressed with a set of macroeconomic variables including economic freedom indexes.

In the first series of regressions ordinary least squares (OLS) in crossectional data of yearly averaged option metrics were used. The crossectional regression data were prepared by using arithmetic mean for the daily prices of option ask and bid, creating an annual bid-ask spread for puts and calls. Regarding volume, open interest and implied volatility the total annual amounts for the years 2012-2016 were calculated.

The panel data models used include random effects, fixed effects and linear dynamic panel-data. The panel data were formulated as per Bruno (2005).

Heteroskedasticity was tested with the used of Breusch-Pagan Test and autocorrelation with the use of Breusch-Godfrey (Regress Time Series-Postestimation Tools for Regress with Time Series, 2013) test and Wooldridge's test (Xtreg-, Fixed-, between-, and Random-Effects and Population-Averaged Linear Models, 2013) for panel data models and corrected when foundusing Robust Standard Errors and Vector robust Standard errors (Regress-Linear Regression, 2013) for crossectional and panel data we corrected accordingly using the Huber/White/ sandwich VC Estimator (Vce Options-Variance Estimators, 2013). The regressions $1,3,5,9,13,16,22,24,25,29,30,32,37,41,42,45,47,48,49,50,51,56$, $57,62,63,64,65,69,70$ were corrected for heteroskedasticity. The regressions 2 , $3,5,9,13,14,16,22,24,25,26,30,32,37,38,39,40,44,45,47,49,50,51,56,57$, $58,61,62,65,68$ were corrected for autocorrelation. A reference table can be found on Appendix 3.

\subsection{Crossectional Models}

A multivariate OLS regression was used on the crossectional data using Stata (Regress-Linear regression, 2013) to calculate the coefficients and error terms.

$$
Y_{i}=a+\beta_{1} x_{1}+\cdots+\beta_{i} x_{i}+e_{i}, \text { for } i=1, \cdots, n
$$

\subsection{Fixed Effects}

The methodology as presented in the Stata manual (Xtreg-, Fixed-, between-, and Random-Effects and Population-Averaged Linear Models, 2013) was followed. The model:

$$
Y_{i t}=a+\beta x_{i t}+v_{i}+e_{i t}, \text { for } i=1, \cdots, n \text { and } t=1, \cdots, T
$$

was fit and Stata software was used to produce the estimates running OLS on:

$$
\left(y_{i t}-\bar{y}_{t}+\overline{\bar{y}}\right)=a+\left(c_{i t}-\bar{c}_{t}+\overline{\bar{v}}\right)+\left(\chi_{i t}-\bar{x}_{t}+\overline{\bar{x}}\right) \beta+\overline{\bar{c}} .
$$

Estimates of $u_{i}$ and $v_{i}$ are given by: 


$$
u_{i}=\bar{y}_{i}-\hat{a}-\bar{x}_{i} \hat{\beta}
$$

\subsection{Random Effects}

Random Effects estimator makes use of the generalized least squares (GLS) transform $\check{Z}$ (for a variable $z$, given the idiosyncratic component $\hat{\sigma}_{e}^{2}$ and the individual component $\hat{\sigma}_{u}^{2}$ )

$$
\begin{gathered}
\check{z}_{i t}=z_{i t}-z_{i} \hat{\theta}_{t}, \\
\hat{\theta}_{t}=1-\sqrt{\frac{\hat{\sigma}_{e}^{2}}{T_{i} \hat{\sigma}_{u}^{2}+\hat{\sigma}_{e}^{2}}} .
\end{gathered}
$$

Getting the estimate of $\hat{\theta}_{t}$ the independent and dependent variables are transformed and this transformed estimate, as well as the transformed constant $1-\hat{\theta}_{t}$ is used to run the OLS regression in order to produce the variance-covamriance matrix. The variance components are calculated by using the SwamyArora method (Xtreg-, Fixed-, between-, and Random-Effects and PopulationAveraged Linear Models, 2013), estimating the idiosyncratic error component $\hat{\sigma}_{e}^{2}$ as

$$
\begin{gathered}
\hat{\sigma}_{e}^{2}=\frac{\sum_{i}^{n} \sum_{t}^{T} e_{i t}^{2}}{N-n-K+1}, \\
e_{i t}=\left(y_{i t}-\bar{y}_{t}+\overline{\bar{y}}\right)-\hat{a}_{w}+\left(\chi_{i t}-\bar{x}_{t}+\overline{\bar{x}}\right) \hat{\beta}_{w},
\end{gathered}
$$

and the individual error component $\hat{\sigma}_{u}^{2}$ as

$$
\begin{aligned}
& \hat{\sigma}_{u \bar{T}}^{2}=\max \left\{0, \frac{S S R_{b}}{n-K}-\frac{\hat{\sigma}_{e}^{2}}{\bar{T}}\right\}, \\
& S_{S R_{b}}=\sum_{i}^{n}\left(\bar{y}_{t}-\hat{a}_{b}-\bar{x}_{t} \hat{\beta}_{b}\right),
\end{aligned}
$$

where $\bar{T}$ is the harmonic mean of $T_{i}$ and $\hat{a}_{b}, \hat{\beta}_{b}$ the coefficient estimates. The standard deviation of $e_{i t}+v_{i}$ is calculated as

$$
\sqrt{\hat{\sigma}_{e}^{2}+\hat{\sigma}_{u}^{2}} \text {. }
$$

The fixed effects model is a common choice for macroeconomists. It is generally more appropriate than a random effects model for many macro datasets mainly because, if the individual effect represents omitted variables, it is highly likely that these country-specific characteristics are correlated with the other regressors. But the dataset employed, in contrast with a typical macro panel, which contains most of the countries of interest, is more likely to be a random sample from a much larger universe of European option markets. Thus, the case of random effects model is examined as well.

\subsection{Dynamic Panel Data}

The generic form of a panel data dynamic regression equation (Baltagi, 2013) is:

$$
y_{i t}=\sum_{J=1}^{P} a_{j} y_{i, t-j}+x_{i t} \beta_{1}+w_{i t} \beta_{2}+v_{i}+\varepsilon_{i t}, \quad i=1, \cdots, N ; t=1, \cdots, T_{i}
$$


where:

$a_{j, p}$ are parametersbeing estimated,

$x_{i t}$ is a $1 \times k_{1}$ vector of strictly exogenous covariates,

$\beta_{1}$ is a $k_{1} \times 1$ vector of parameters to be estimated,

$w_{i t}$ is a $1 \times k_{2}$ vector of predetermined and endogenous covariates,

$\beta_{2}$ is a $k_{2} \times 1$ vector of parameters to be estimated,

$v_{i}$ are the panel-level effects (which may be correlated with the covariates), and $e_{i t}$ are i.i.d. over the whole sample with variance $\sigma_{t}^{2}$.

By construction, the lagged dependent variables are correlated with the unobserved panel-level effects, making standard estimators inconsistent. With many panels and few periods, estimators are constructed by first-differencing to remove the panel-level effects and using instruments to form moment conditions. Stata uses a generalized method of moments (GMM) estimator to estimate the coefficients (Xtabond-Arellano-Bond Linear Dynamic Panel-Data Estimation, 2013). The moment conditions are formed from the first-differenced errors from $y_{i t}$. Lagged levels of the dependent variable, the predetermined variables and the endogenous variables are used to form GMM-type instruments (Xtdpd-Linear Dynamic Panel-Data Estimation, 2013).

\section{Regression Summary}

The particulars of the regressions ran appear in the following Tables 4-12. Tables 3-6 exhibit the cross-sectional OLS regressions. Table 7 presents the fixed effects regressions, Table 8 presents the random effects regressions, whereas Tables 9-12 show the dynamic panel data regressions. Their explanation is given in the following section and their implications are drafted in the section that follows it.

Table 3. Regression summary Crossectional OLS

\section{Dependent Variables}

Call Bid-Ask Spread

(1)

(2)

(3)

(4)

(5)

Put Bid-Ask Spread

Volume

Open Interest

Implied Volatility

\begin{tabular}{ccccc}
\hline Independent Variables & & & \\
\hline GDP & $-1.12 \mathrm{e}-10^{* *}$ & $0.0000127^{*}$ & $-6.49 \mathrm{e}-12^{* *}$ & $(6.28 \mathrm{e}-13)$ \\
& $(4.09 \mathrm{e}-11)$ & $(5.72 \mathrm{e}-06)$ & & $-1.459117^{\star *}$ \\
Economic Freedom & & $-3.301068^{\star}$ & $(0.6112409)$ \\
Freedom from Corruption & & $(1.885611)$ & $-1.668924^{* * *}$ & $(0.4237151)$ \\
\hline
\end{tabular}




\section{Continued}

\begin{tabular}{|c|c|c|c|c|c|c|c|}
\hline Market Capitalization of Listed & $9.25 \mathrm{e}-11^{\star \star}$ & & & & & $-2.66 \mathrm{e}-12^{\star *}$ & \\
\hline Domestic Companies & $(1.00 \mathrm{e}-12)$ & & & & & $(6.75 e-13)$ & \\
\hline Stocks Traded, Turnover Ratio & $-8.45 e-11^{\star *}$ & & & & & $9.34 \mathrm{e}-12^{\star *}$ & \\
\hline of Domestic Shares (\%) & $(2.49 \mathrm{e}-12)$ & & & & & $(5.99 \mathrm{e}-13)$ & \\
\hline Stocks Traded, Total Value & & & & & & $\begin{array}{c}-0.0116885 \\
(0.00277668)\end{array}$ & \\
\hline Public Debt \% Of GDP & & & $\begin{array}{c}0.450316^{*} \\
(0.2836016)\end{array}$ & & & & \\
\hline GDP per capita & $\begin{array}{l}0.0009507^{\star *} \\
(1.90 \mathrm{e}-11)\end{array}$ & & & & & $\begin{array}{l}0.000087^{\star} \\
(0.0001411)\end{array}$ & \\
\hline Constant & $\begin{array}{c}-6,738,532^{\star *} \\
(108,099)\end{array}$ & $\begin{array}{c}2.394379 \\
(3.241566)\end{array}$ & $\begin{array}{c}-13.95679 \\
(16.2758)\end{array}$ & $\begin{array}{c}252.1953 \\
(85.36659)\end{array}$ & $\begin{array}{c}148.1147^{* * *} \\
(35.62484)\end{array}$ & $\begin{array}{c}-4,780,632^{\star \star} \\
(156,474)\end{array}$ & $\begin{array}{l}1,146,772^{* *} \\
(4,343,483)\end{array}$ \\
\hline
\end{tabular}

Source: author estimations with data from DataStream (2017), World Bank Open Data (2017) and The Heritage Foundation (2012)-(2016). Note: standard errors appear in parenthesis; ${ }^{* *}$ statistically significant at the $1 \%$ level; ${ }^{* *}$ statistically significant at the $5 \%$ level; ${ }^{*}$ statistically significant at the $10 \%$ level.

Table 4. Regression summary Crossectional OLS.

\begin{tabular}{|c|c|c|c|c|c|c|c|}
\hline$\underline{\text { Dependent Variables }}$ & & & & & & & \\
\hline \multicolumn{8}{|l|}{ Call Bid-Ask Spread } \\
\hline \multicolumn{8}{|l|}{ Volume } \\
\hline \multicolumn{8}{|l|}{ Open Interest } \\
\hline \multicolumn{8}{|l|}{ Implied Volatility } \\
\hline \multicolumn{8}{|l|}{$\underline{\text { Independent Variables }}$} \\
\hline Unemployment (\%) & & $\begin{array}{l}2.101969^{* * *} \\
(0.3268943)\end{array}$ & & & & & \\
\hline Freedom from Corruption & & & & $\begin{array}{c}-0.8063508^{*} \\
(0.1397484)\end{array}$ & & & \\
\hline Business Freedom & $\begin{array}{l}-1.069185^{*} \\
(0.5422312)\end{array}$ & & & & & & \\
\hline Financial Freedom & & & & & $\begin{array}{c}-0.8867756^{*} \\
(0.4565407)\end{array}$ & & \\
\hline Public Debt \% Of GDP & & & & & & $\begin{array}{l}0.3305203^{*} \\
(0.1211476)\end{array}$ & \\
\hline GDP per capita & & & & & & & $\begin{array}{l}-0.0011759^{*} \\
(0.0006577)\end{array}$ \\
\hline Property rights & & & $\begin{array}{l}-1.000618^{\star *} \\
(0.1824788)\end{array}$ & & & & \\
\hline Constant & $\begin{array}{c}102.8538^{\star *} \\
(49.3788)\end{array}$ & $\begin{array}{l}-4.350308 \\
(5.029552)\end{array}$ & $\begin{array}{c}95.47905^{\star * *} \\
(16.77442)\end{array}$ & $\begin{array}{l}74.01295^{\star * *} \\
(12.68622)\end{array}$ & $\begin{array}{l}76.43632^{\star *} \\
(33.72155)\end{array}$ & $\begin{array}{l}-12.72088 \\
(9.346081)\end{array}$ & $\begin{array}{l}59.05018^{\star} \\
(28.22754)\end{array}$ \\
\hline
\end{tabular}

Source: author estimations with data from DataStream (2017), World Bank Open Data (2017) and The Heritage Foundation (2012)-(2016). Note: standard errors appear in parenthesis; ${ }^{* *}$ statistically significant at the $1 \%$ level; ${ }^{* *}$ statistically significant at the $5 \%$ level; ${ }^{*}$ statistically significant at the $10 \%$ level. 
Table 5. Regression summary Crossectional OLS.

\section{Dependent Variables}

Call Bid-Ask Spread

Put Bid-Ask Spread

$$
\text { Volume }
$$

(16)

(17)

(18)

Open Interest

(19)

(20)

(21)

Implied Volatility

\begin{tabular}{|c|c|c|c|c|c|c|c|}
\hline Independent Variables & & & & & & & \\
\hline GDP & $\begin{array}{l}-6.57 \mathrm{e}-06^{* *} \\
(1.17 \mathrm{e}-07)\end{array}$ & & $\begin{array}{l}9.996616^{* *} \\
(4.302711)\end{array}$ & & $\begin{array}{l}0.0000397^{* *} \\
(0.0000253)\end{array}$ & & \\
\hline $\begin{array}{c}\text { Unemployment (\%) } \\
\text { Population }\end{array}$ & & $\begin{array}{l}0.3243298^{*} \\
(0.1881145)\end{array}$ & & & & & $\begin{array}{l}2.67 \mathrm{e}+07^{\star *} \\
(8090922)\end{array}$ \\
\hline $\begin{array}{c}\text { Stocks Traded, Turnover Ratio } \\
\text { of Domestic Shares (\%) }\end{array}$ & $\begin{array}{l}2.51 \mathrm{e}-06^{* *} \\
(1.11 \mathrm{e}-07)\end{array}$ & & & & $\begin{array}{l}0.0002382^{\star *} \\
(0.0000242)\end{array}$ & & \\
\hline Stocks Traded, Total Value & $\begin{array}{l}74,094.95^{\star *} \\
(5,164,236)\end{array}$ & & & & $\begin{array}{l}719303^{* *} \\
(112,141.1)\end{array}$ & & \\
\hline Corporate Tax Rate (\%) & & & & $\begin{array}{l}-2,115,851^{*} \\
(1,134,450)\end{array}$ & & & \\
\hline $\begin{array}{c}\text { Market Capitalization of } \\
\text { Listed Domestic Companies }\end{array}$ & $\begin{array}{l}5.76 \mathrm{e}-06^{* *} \\
(1.26 \mathrm{e}-07)\end{array}$ & & & & $\begin{array}{l}-0.000192^{\star *} \\
(0.0000273)\end{array}$ & & \\
\hline GDP per capita & $\begin{array}{l}2,243,253^{* *} \\
(262,494)\end{array}$ & & & & $\begin{array}{l}2,532,586^{* *} \\
(5,700,057)\end{array}$ & & \\
\hline FDI inflows & & & & & & $\begin{array}{l}35,856.6^{*} \\
(17,250.2)\end{array}$ & \\
\hline Constant & $\begin{array}{c}-4,427,334^{* *} \\
(291,021)\end{array}$ & $\begin{array}{l}1,492,168 \\
(312,493)\end{array}$ & $\begin{array}{l}-1,178,035 \\
(3,191,489)\end{array}$ & $\begin{array}{l}6.48 \mathrm{e}+07^{\star} \\
(3.06 \mathrm{e}+07)\end{array}$ & $\begin{array}{l}-5.12 \mathrm{e}+07^{*} \\
(6.32 \mathrm{e}+06)\end{array}$ & $\begin{array}{l}-1.94 \mathrm{e}+07 \\
(3.64 \mathrm{e}+08)\end{array}$ & $\begin{array}{r}-1.95 \mathrm{e}+08^{* *} \\
(7.49 \mathrm{e}+07)\end{array}$ \\
\hline
\end{tabular}

Source: author estimations with data from DataStream (2017), World Bank Open Data (2017) and The Heritage Foundation (2012)-(2016). Note: standard errors appear in parenthesis; ${ }^{* * *}$ statistically significant at the $1 \%$ level; ${ }^{* *}$ statistically significant at the $5 \%$ level; ${ }^{*}$ statistically significant at the $10 \%$ level.

Table 6. Regression summary Crossectional OLS.

\section{Dependent Variables}

Call Bid-Ask Spread

Put Bid-Ask Spread

Volume

Open Interest

(22)

Implied Volatility

(23)

(24)

(25)

(26)

(27)

(28) 


\section{Continued}

\begin{tabular}{|c|c|c|c|c|c|c|c|}
\hline$\underline{\text { Independent Variables }}$ & & & & & & & \\
\hline GDP & $\begin{array}{l}751,799^{* * *} \\
(208,891)\end{array}$ & $\begin{array}{l}-1.70 \mathrm{e}-14^{* *} \\
(2.18 \mathrm{e}-15)\end{array}$ & & & & & \\
\hline Economic Freedom & & & & & & $\begin{array}{l}-0.015657^{* * *} \\
(0.0048792)\end{array}$ & \\
\hline Freedom from Corruption & & & & & & & $\begin{array}{r}-0.0038567^{*} \\
(0.0019588)\end{array}$ \\
\hline Trade Freedom & & & & $\begin{array}{c}-0.0563123^{* * *} \\
(0.018001)\end{array}$ & & & \\
\hline Investment Freedom & & & & & $\begin{array}{c}-0.0109724^{* * *} \\
(0.0031528)\end{array}$ & & \\
\hline $\begin{array}{c}\text { Market Capitalization of } \\
\text { Listed Domestic Companies }\end{array}$ & & $\begin{array}{l}7.00 \mathrm{e}-14^{* *} \\
(2.34 \mathrm{e}-15)\end{array}$ & & & & & \\
\hline $\begin{array}{c}\text { Stocks Traded, Turnover } \\
\text { Ratio of Domestic Shares (\%) }\end{array}$ & & $\begin{array}{r}-1.08 \mathrm{e}-13^{* *} \\
(2.08 \mathrm{e}-14)\end{array}$ & & & & & \\
\hline Stocks Traded, Total Value & & $\begin{array}{l}0.0000954^{* *} \\
(0.0000963)\end{array}$ & & & & & \\
\hline GDP per capita & & $\begin{array}{l}7.42 \mathrm{e}-07^{* *} \\
(4.89 \mathrm{e}-08)\end{array}$ & & & & & \\
\hline Property rights & & & $\begin{array}{l}-0.0039669^{*} \\
(0.0021449)\end{array}$ & & & & \\
\hline Constant & $\begin{array}{l}-2.27 \mathrm{e}+08^{* *} \\
(8.84 \mathrm{e}+07)\end{array}$ & $\begin{array}{l}0.1609247^{* * *} \\
-0.0542423\end{array}$ & $\begin{array}{l}0.6213668^{* *} \\
(0.176949)\end{array}$ & $\begin{array}{l}5.210393^{* * *} \\
(1.580367)\end{array}$ & $\begin{array}{l}1.210243^{* * *} \\
(0.2629036)\end{array}$ & $\begin{array}{l}1.398849^{* * *} \\
(0.3435486)\end{array}$ & $\begin{array}{l}0.5890259^{* * *} \\
(0.1504588)\end{array}$ \\
\hline
\end{tabular}

Source: author estimations with data from DataStream (2017), World Bank Open Data (2017) and The Heritage Foundation (2012)-(2016). Note: standard errors appear in parenthesis; ${ }^{* *}$ statistically significant at the $1 \%$ level; ${ }^{* *}$ statistically significant at the $5 \%$ level; ${ }^{*}$ statistically significant at the $10 \%$ level.

Table 7. Regression summary fixed effects.

\section{$\underline{\text { Dependent Variables }}$}

Call Bid-Ask Spread

(29)

Put Bid-Ask Spread

(30)

Volume

Open Interest

(32)

Implied Volatility

(33)

(34)

Independent Variables

$\log (G D P)$

$-9.83 e-11$

$7,377,928^{* *}$

$1.14 \mathrm{e}+10^{\star *}$

$1.53 \mathrm{e}-13$

(2.61e-11)

(3.36)

(0.92)

(7.13e-140)

GDP per capita

$-0.0042462$

0.0011669

$-7524.3$

$-0.0000109$

(0.0016153)

$(0.0027849)$

$(51,259.72)$

(5.08e-06) 


\section{Continued}

\begin{tabular}{|c|c|c|c|c|c|c|}
\hline Unemployment (\%) & $\begin{array}{l}-0.0000473 \\
(-1,371,091)\end{array}$ & & $\begin{array}{l}-0.0000177 \\
(6,440,153)\end{array}$ & $\begin{array}{l}-5,374,268 \\
(9.27 \mathrm{e}+07)\end{array}$ & & $\begin{array}{r}-0.0184^{*} \\
(-1.90)\end{array}$ \\
\hline Log (Population) & $\begin{array}{c}288,594 \\
(-0.0000473)\end{array}$ & & $\begin{array}{l}5,174,138^{\star *} \\
(-0.0000177)\end{array}$ & $\begin{array}{c}1.63 e+08^{*} \\
(-5,374,268)\end{array}$ & & $\begin{array}{c}0.0136387 \\
(-2.33 e-08)\end{array}$ \\
\hline Public Debt \% Of GDP & $\begin{array}{c}0.0812835 \\
(0.2777827)\end{array}$ & & $\begin{array}{c}-149,493 \\
(0.5513241)\end{array}$ & $\begin{array}{l}2,098,343 \\
(1.54 \mathrm{e}+07)\end{array}$ & & $\begin{array}{l}-0.0026365 \\
(0.0015976)\end{array}$ \\
\hline Bank Capital to Assets Ratio (\%) & $\begin{array}{c}1,441,537 \\
(7,385,669)\end{array}$ & & $\begin{array}{c}-168,478 \\
(8,585,465)\end{array}$ & $\begin{array}{l}-3.88 \mathrm{e}+08 \\
(3.14 \mathrm{e}+08)\end{array}$ & & $\begin{array}{l}-0.039154^{\star * *} \\
(0.0255095)\end{array}$ \\
\hline Inflation (\%) & $\begin{array}{l}-5,227,663 \\
(2,499,113)\end{array}$ & & $\begin{array}{c}5,366,343 \\
(3,934,968)\end{array}$ & $\begin{array}{c}1.48 \mathrm{e}+08 \\
(1.32 \mathrm{e}+08)\end{array}$ & & $\begin{array}{l}-0.009728 \\
(0.0116139)\end{array}$ \\
\hline Economic Freedom & $\begin{array}{l}0.2417237 \\
(0.7376049)\end{array}$ & & $\begin{array}{l}3,952,484^{* * *} \\
(0.8598988)\end{array}$ & $\begin{array}{l}3.17 \mathrm{e}+07^{\star} \\
(2.95 \mathrm{e}+07)\end{array}$ & & $\begin{array}{c}0.0056449 \\
(0.0032589)\end{array}$ \\
\hline $\begin{array}{l}\text { Interest Rates (Gov Bonds) } \\
10 \text { Year }\end{array}$ & $\begin{array}{l}-2,242,687 \\
(7,791,506)\end{array}$ & & $\begin{array}{l}-1,758,032 \\
(1,573,075)\end{array}$ & $\begin{array}{c}1.99 \mathrm{e}+08 \\
(4.69 \mathrm{e}+08)\end{array}$ & & $\begin{array}{l}0.0423153^{*} \\
(0.0390141)\end{array}$ \\
\hline Freedom from Corruption & $\begin{array}{l}-2357458^{\star *} \\
(5,197,108)\end{array}$ & & $\begin{array}{c}-1,280,415^{\star * *} \\
(7,280,564)\end{array}$ & $\begin{array}{l}-2.40 \mathrm{e}+07^{\star} \\
(1.48 \mathrm{e}+08)\end{array}$ & & $\begin{array}{l}-0.0084223 \\
(0.0155655)\end{array}$ \\
\hline Fiscal Freedom & $\begin{array}{l}-1,687,506 \\
(5,969,377)\end{array}$ & & $\begin{array}{l}2,933,173^{* * *} \\
(1,184,746)\end{array}$ & $\begin{array}{l}1.71 \mathrm{e}+08^{*} \\
(2.77 \mathrm{e}+08)\end{array}$ & & $\begin{array}{l}0.0299604^{*} \\
(0.0323083)\end{array}$ \\
\hline Business Freedom & $\begin{array}{l}-0.7738089 \\
(1,282,749)\end{array}$ & & $\begin{array}{c}-8,226,478^{* *} \\
(272,878)\end{array}$ & $\begin{array}{l}-7.44 \mathrm{e}+07^{\star} \\
(6.25 \mathrm{e}+07)\end{array}$ & & $\begin{array}{c}-0.0107303^{* * *} \\
(0.0063113)\end{array}$ \\
\hline Investment Freedom & $\begin{array}{c}1,111,043 \\
(1,386,519)\end{array}$ & & $\begin{array}{l}-4,123,394 \\
(2,016,895)\end{array}$ & $\begin{array}{l}-2.44 \mathrm{e}+07 \\
(7.47 \mathrm{e}+07)\end{array}$ & & $\begin{array}{l}-0.0018179 \\
(0.0053503)\end{array}$ \\
\hline Income Tax Rate (\%) & $\begin{array}{l}1,909,797^{* * *} \\
(8,425,393)\end{array}$ & & $\begin{array}{l}2,657,176^{\star *} \\
(1,254,226)\end{array}$ & $\begin{array}{l}1.62 \mathrm{e}+08^{*} \\
(3.27 \mathrm{e}+08)\end{array}$ & & $\begin{array}{l}0.0362286 \\
(0.0389402)\end{array}$ \\
\hline Corporate Tax Rate (\%) & $\begin{array}{c}7,529,284 \\
(2,273,524)\end{array}$ & & $\begin{array}{l}1,248,394 \\
(300,873)\end{array}$ & $\begin{array}{l}-2.67 e+08 \\
(9.81 e+08)\end{array}$ & & $\begin{array}{l}-0.1695433^{*} \\
(0.0677029)\end{array}$ \\
\hline Financial Freedom & $\begin{array}{c}6,548,763 \\
(6,361,956)\end{array}$ & & $\begin{array}{c}1,801,701 \\
(7,631,008)\end{array}$ & $\begin{array}{l}-6.12 \mathrm{e}+09 \\
(1.99 \mathrm{e}+09)\end{array}$ & & $\begin{array}{l}-0.2027718 \\
(0.168976)\end{array}$ \\
\hline $\begin{array}{c}\text { Market Capitalization of Listed } \\
\text { Domestic Companies }\end{array}$ & $\begin{array}{c}1.45 \mathrm{e}-11 \\
(2.14 \mathrm{e}-11)\end{array}$ & & $\begin{array}{c}2.00 \mathrm{e}-11 \\
(2.14 \mathrm{e}-11)\end{array}$ & $\begin{array}{l}0.0003289 \\
(0.0004678)\end{array}$ & & $\begin{array}{c}1.49 \mathrm{e}-14 \\
(2.92 \mathrm{e}-14)\end{array}$ \\
\hline $\begin{array}{c}\text { S\&P Global Equity } \\
\text { Indices (Annual \% Change) }\end{array}$ & $\begin{array}{l}-0.7347998 \\
(0.0939463)\end{array}$ & & $\begin{array}{l}-0.9809123 \\
(0.1781333)\end{array}$ & $\begin{array}{l}-6693247^{* *} \\
(3,493,916)\end{array}$ & $0.0006^{\star *}$ & $\begin{array}{l}0.0000979^{*} \\
(0.0003421)\end{array}$ \\
\hline $\begin{array}{c}\text { Stocks Traded, Turnover Ratio } \\
\text { of Domestic Shares (\%) }\end{array}$ & $\begin{array}{l}9.63 \mathrm{e}-11^{* *} \\
(5.40 \mathrm{e}-11)\end{array}$ & & $\begin{array}{l}4.39 \mathrm{e}-11^{\star * *} \\
(5.88 \mathrm{e}-11)\end{array}$ & $\begin{array}{l}-0.0013783^{*} \\
(0.0016434)\end{array}$ & $(2.34)$ & $\begin{array}{l}-1.60 e-13^{*} \\
(1.99 e-13)\end{array}$ \\
\hline Stocks Traded, Total Value & $\begin{array}{l}-0.4808714 \\
(0.3056932)\end{array}$ & $\begin{array}{c}-0.171^{\star * *} \\
(-5.21)\end{array}$ & $\begin{array}{l}0.1251975^{* * *} \\
(0.3387303)\end{array}$ & $\begin{array}{l}7,508,647^{\star} \\
(1.05 \mathrm{e}+07)\end{array}$ & & $\begin{array}{l}0.0009984^{*} \\
(0.0011633)\end{array}$ \\
\hline Constant & $\begin{array}{r}-44,955.63^{* *} \\
(4,598,113)\end{array}$ & $\begin{array}{c}2,557,756^{* * *} \\
(878,505)\end{array}$ & $\begin{array}{c}-1941.44 \\
(5,382,439)\end{array}$ & $\begin{array}{c}4.49 \mathrm{e}+11^{\star * *} \\
(1.41 \mathrm{e}+11)\end{array}$ & $\begin{array}{c}0.3100664^{* * *} \\
(0.0017345)\end{array}$ & $\begin{array}{c}9,649,115 \\
(1,135,567)\end{array}$ \\
\hline
\end{tabular}

Source: author estimations with data from DataStream (2017), World Bank Open Data (2017) and The Heritage Foundation (2012)-(2016). Note: standard errors appear in parenthesis; ${ }^{* *}$ statistically significant at the $1 \%$ level; ${ }^{* *}$ statistically significant at the $5 \%$ level; ${ }^{*}$ statistically significant at the $10 \%$ level. 
Table 8. Regression summary random effects.

\section{Dependent Variables}

Call Bid-Ask Spread

(35)

(36)

Put Bid-Ask Spread

Volume

Open Interest

(38)

Implied Volatility

(39)

Independent Variables

\begin{tabular}{|c|c|c|c|c|c|}
\hline $\log (\mathrm{GDP})$ & $\begin{array}{c}3.04 \mathrm{e}-11 \\
(1.85 \mathrm{e}-11)\end{array}$ & $\begin{array}{l}-2.37 \mathrm{e}-11 \\
(2.16 \mathrm{e}-11)\end{array}$ & $\begin{array}{l}0.0000235 \\
(8.43 \mathrm{e}-06)\end{array}$ & $\begin{array}{l}0.0001685 \\
(0.0007229)\end{array}$ & $\begin{array}{c}1.03 \mathrm{e}-13 \\
(4.34 \mathrm{e}-14)\end{array}$ \\
\hline GDP per capita & $\begin{array}{l}-0.0008962 \\
(0.0020782)\end{array}$ & $\begin{array}{l}-0.0014959 \\
(0.0015178)\end{array}$ & $\begin{array}{c}5,523,282 \\
(4,729,704)\end{array}$ & $\begin{array}{c}5,829,452 \\
(23,218.79)\end{array}$ & $\begin{array}{l}-6.54 \mathrm{e}-06 \\
(1.33 \mathrm{e}-06)\end{array}$ \\
\hline Unemployment (\%) & $\begin{array}{l}-3.80 \mathrm{e}-06 \\
(5,222,666)\end{array}$ & $\begin{array}{l}-8.84 \mathrm{e}-07 \\
(1,603,924)\end{array}$ & $\begin{array}{l}0.0864748 \\
(25,034.4)\end{array}$ & $\begin{array}{c}4,876,369 \\
(-9.18 \mathrm{e}+07)\end{array}$ & $\begin{array}{c}-2.24 \mathrm{e}-09 \\
(-0.0165008)\end{array}$ \\
\hline Log (Population) & $\begin{array}{c}4,066,669 \\
(-3.80 \mathrm{e}-06)\end{array}$ & $\begin{array}{c}4,966,175 \\
(-8.84 \mathrm{e}-07)\end{array}$ & $\begin{array}{c}2,286,598 \\
(0.0864748)\end{array}$ & $\begin{array}{c}1.50 \mathrm{e}+08 \\
(4,876,369)\end{array}$ & $\begin{array}{l}0.0036199^{* * *} \\
(-2.24 \mathrm{e}-09)\end{array}$ \\
\hline Public Debt \% Of GDP & $\begin{array}{l}-0.7869933 \\
(1,156,745)\end{array}$ & $\begin{array}{l}-1,109,088 \\
(0.6399793)\end{array}$ & $\begin{array}{l}-80,727.04 \\
(202,937.3)\end{array}$ & $\begin{array}{l}8,956,468 \\
(1.62 \mathrm{e}+07)\end{array}$ & $\begin{array}{l}-0.0035088 \\
(0.001445)\end{array}$ \\
\hline $\begin{array}{l}\text { Bank Capital to } \\
\text { Assets Ratio (\%) }\end{array}$ & $\begin{array}{l}-9722102 \\
(1,444,585)\end{array}$ & $\begin{array}{l}1,473,033^{* * *} \\
(1,206,198)\end{array}$ & $\begin{array}{c}-551,979^{* * *} \\
(384,295)\end{array}$ & $\begin{array}{c}1.22 \mathrm{e}+08 \\
(2.16 \mathrm{e}+08)\end{array}$ & $\begin{array}{l}-0.0234583 \\
(0.0132522)\end{array}$ \\
\hline Inflation (\%) & $\begin{array}{l}-0.3084574 \\
(3,139,013)\end{array}$ & $\begin{array}{l}2,845,764 \\
(5,654,011)\end{array}$ & $\begin{array}{l}-1,635,805 \\
(1,312,211)\end{array}$ & $\begin{array}{c}3.79 e+07 \\
(1.43 e+08)\end{array}$ & $\begin{array}{l}0.0004861 \\
(0.006932)\end{array}$ \\
\hline Economic Freedom & $\begin{array}{l}-1561838 \\
(1,899,719)\end{array}$ & $\begin{array}{l}0.6572755 \\
(2,157,497)\end{array}$ & $\begin{array}{l}-1,082,200^{* *} \\
(563,528.6)\end{array}$ & $\begin{array}{l}-2.31 \mathrm{e}+07 \\
(4.53 \mathrm{e}+07)\end{array}$ & $\begin{array}{l}0.0008498 \\
(0.0031195)\end{array}$ \\
\hline $\begin{array}{l}\text { Interest Rates (Gov } \\
\text { Bonds) } 10 \text { Year }\end{array}$ & $\begin{array}{c}-4,490,122^{* *} \\
(1,242,055)\end{array}$ & $\begin{array}{l}-4111495^{\star *} \\
(1,062,798)\end{array}$ & $\begin{array}{l}-519,891.5 \\
(1,343,819)\end{array}$ & $\begin{array}{l}-3.63 e+07 \\
(2.60 e+08)\end{array}$ & $\begin{array}{l}0.0145965 \\
(0.0095867)\end{array}$ \\
\hline Freedom from Corruption & $\begin{array}{l}-2,639,384 \\
(5,533,023)\end{array}$ & $\begin{array}{l}-0.853028^{* *} \\
(2,822,251)\end{array}$ & $\begin{array}{l}-1,060,994 \\
(773,117.1)\end{array}$ & $\begin{array}{c}2.93 \mathrm{e}+07 \\
(2.90 \mathrm{e}+07)\end{array}$ & $\begin{array}{c}-0.000271 \\
(0.0065121)\end{array}$ \\
\hline Fiscal Freedom & $\begin{array}{l}-5,052,756 \\
(1,102,719)\end{array}$ & $\begin{array}{l}-0.3909706 \\
(7,730,906)\end{array}$ & $\begin{array}{c}1,094,639 \\
(3,196,039)\end{array}$ & $\begin{array}{c}1.03 \mathrm{e}+08 \\
(1.71 \mathrm{e}+08)\end{array}$ & $\begin{array}{l}-0.0089019 \\
(0.0080985)\end{array}$ \\
\hline Business Freedom & $\begin{array}{l}-1,249,726 \\
(3,928,377)\end{array}$ & $\begin{array}{l}-1,389,615 \\
(2,165,426)\end{array}$ & $\begin{array}{c}1,539,349^{* * *} \\
(770,675)\end{array}$ & $\begin{array}{c}2.99 \mathrm{e}+07 \\
(5.26 \mathrm{e}+07)\end{array}$ & $\begin{array}{c}-0.0077038^{* *} \\
(0.0050599)\end{array}$ \\
\hline Investment Freedom & $\begin{array}{l}-2,063,552 \\
(2,976,293)\end{array}$ & $\begin{array}{l}-0.745197 \\
(2,717,522)\end{array}$ & $\begin{array}{l}-488,897^{\star *} \\
(915,335.9)\end{array}$ & $\begin{array}{l}-3.10 e+07 \\
(3.69 e+07)\end{array}$ & $\begin{array}{l}-0.0070047 \\
(0.0050848)\end{array}$ \\
\hline Income Tax Rate (\%) & $\begin{array}{l}-6,182,334 \\
(8,333,543)\end{array}$ & $\begin{array}{l}-2,546,851 \\
(9,941,428)\end{array}$ & $\begin{array}{c}3,448,664 \\
(4,310,762)\end{array}$ & $\begin{array}{c}1.66 \mathrm{e}+08 \\
(2.80 \mathrm{e}+08)\end{array}$ & $\begin{array}{l}-0.0103391 \\
(0.0067985)\end{array}$ \\
\hline Corporate Tax Rate (\%) & $\begin{array}{l}-9,746,373 \\
(8,680,848)\end{array}$ & $\begin{array}{c}-3,599,357 \\
(112,352)\end{array}$ & $\begin{array}{c}2,039,977 \\
(2,215,022)\end{array}$ & $\begin{array}{c}1.74 \mathrm{e}+08 \\
(1.56 \mathrm{e}+08)\end{array}$ & $\begin{array}{c}0.00131 \\
(0.0107205)\end{array}$ \\
\hline
\end{tabular}




\section{Continued}

\begin{tabular}{|c|c|c|c|c|c|c|c|}
\hline \multirow{2}{*}{ Financial Freedom } & & $-2,429,196$ & $-4,778,613$ & $4,158,051$ & $3.32 \mathrm{e}+07$ & -0.0062963 & \\
\hline & & $(1,186,915)$ & $(7,365,695)$ & $(3,084,875)$ & $(1.63 e+08)$ & $(0.0148224)$ & \\
\hline \multicolumn{2}{|l|}{ Market Capitalization of Listed } & $5.74 \mathrm{e}-11$ & $1.36 \mathrm{e}-11$ & $1.42 \mathrm{e}-06$ & 0.0000534 & $-8.55 e-14$ & \\
\hline \multicolumn{2}{|l|}{ Domestic Companies } & $(5.30 \mathrm{e}-11)$ & $(2.71 \mathrm{e}-11)$ & $(0.0000116)$ & $(0.0010772)$ & $(6.54 \mathrm{e}-14)$ & \\
\hline \multirow{2}{*}{\multicolumn{2}{|c|}{$\begin{array}{l}\text { S\&P Global Equity Indices } \\
\quad \text { (Annual \% Change) }\end{array}$}} & -0.7461294 & -0.6370572 & $172,094.7$ & $2,014,576$ & 0.0002363 & $0.0006007^{\star *}$ \\
\hline & & $(0.9133799)$ & $(0.5709311)$ & $(265,815.4)$ & $(8,646,852)$ & $(0.000664)$ & $(0.0002567)$ \\
\hline \multirow{2}{*}{\multicolumn{2}{|c|}{$\begin{array}{c}\text { Stocks Traded, Turnover Ratio } \\
\text { of Domestic Shares (\%) }\end{array}$}} & $-6.92 \mathrm{e}-11^{* *}$ & $-1.45 e-11$ & -0.0000349 & 0.0004817 & $2.68 \mathrm{e}-13$ & \\
\hline & & $(6.65 e-11)$ & $(8.38 \mathrm{e}-11)$ & $(0.0000191)$ & $(0.0014138)$ & $(8.91 \mathrm{e}-14)$ & \\
\hline \multirow{2}{*}{ Stocks Traded, Total Value } & $1.56 \mathrm{e}-11^{\star * *}$ & $0.42912^{\star \star}$ & 0.0003415 & $267,631.8$ & $-913,594.4$ & -0.0012293 & \\
\hline & $(1.29 \mathrm{e}-11)$ & $(0.5041878)$ & $(0.574734)$ & $(153,251.3)$ & $(9,417,680)$ & $(0.0006659)$ & \\
\hline \multirow{2}{*}{ Constant } & $2,557,756^{\star * *}$ & $1,782,733^{* * *}$ & $1,106,168^{* *}$ & $-5.97 e+08^{* * *}$ & $-2.38 \mathrm{e}+10$ & $3739635^{\star}$ & $0.3100664^{* * *}$ \\
\hline & (8.78505) & $(1,397,387)$ & $(1,382,201)$ & $(2.73 e+08)$ & $(2.46 e+10)$ & $(0.8271702)$ & $(0.0017345)$ \\
\hline
\end{tabular}

Source: author estimations with data from DataStream (2017), World Bank Open Data (2017) and The Heritage Foundation (2012)-(2016). Note: standard errors appear in parenthesis; ${ }^{* *}$ statistically significant at the $1 \%$ level; ${ }^{* *}$ statistically significant at the $5 \%$ level; ${ }^{*}$ statistically significant at the $10 \%$ level.

Table 9. Regression summary dynamic panel data.

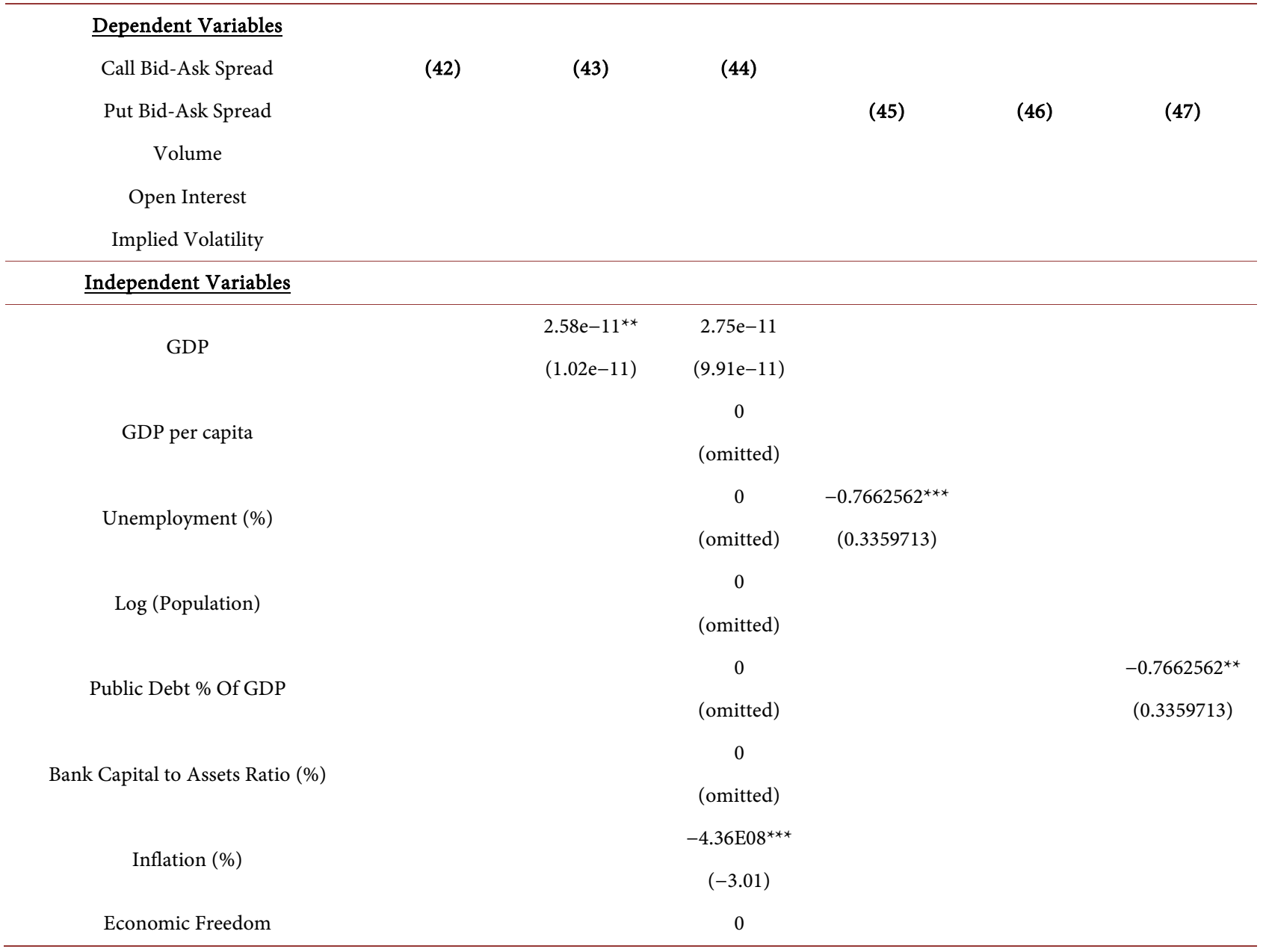




\section{Continued}

Interest Rates (Gov Bonds) 10 Year

Freedom from Corruption

Fiscal Freedom

Business Freedom

Investment Freedom

Income Tax Rate (\%)

Corporate Tax Rate (\%)

Financial Freedom

Market Capitalization of Listed

Domestic Companies

S\&P Global Equity Indices

(Annual \% Change)

Stocks Traded, Turnover Ratio

of Domestic Shares (\%)

Stocks Traded, Total Value

1 Period Lag

Constant (omitted)

$-3,019,439$

$(5,492,788)$

$-6,518,908$

$(1,924,076)$

$-1,127,562$

$(2,980,506)$

$-1,157,423$

$(5,866,613)$

$2,181,582$

$(8,452,077)$

$-1,543,544$

0.1981062

$(3,889,122)$

$(0.0698957)$

$-1,077,862$

$(8,128,698)$

$2,967,133$

$(6,762,979)$

$8.50 \mathrm{e}-11^{* * *}$

$(2.09 \mathrm{e}-11)$

$2.93 \mathrm{e}-11$

(1.63e-10)

$-0.4178227$

(1062312)

$-8.30 \mathrm{e}-12$

$-0.2902138$

$-0.1384774$

(2.89e-10)

(0.118074)

(0.1089451)

$-0.0127623$

7596598

0

$(1,712,933)$

(3195719)

(omitted)

$-0.6853292$

(0.7003205)

0

$$
\begin{gathered}
(0.1194675) \\
-6,844,873^{* * *}
\end{gathered}
$$$$
\text { (0.3904195) }
$$

$-2,372,856$

$(3,422,292)$

(omitted)

$-0.2902138^{\star *}$

(0.1180744)

7596598

(31.95719)

Source: author estimations with data from DataStream (2017), World Bank Open Data (2017) and The Heritage Foundation (2012)-(2016). Note: standard errors appear in parenthesis; ${ }^{* *}$ statistically significant at the $1 \%$ level; ${ }^{* *}$ statistically significant at the $5 \%$ level; ${ }^{*}$ statistically significant at the $10 \%$ level.

Table 10. Regression summary dynamic panel data.

\section{Dependent Variables}

Call Bid-Ask Spread

Put Bid-Ask Spread

(48)

(49)

(50)

Volume

(51)

(52)

(53)

(54)

Implied Volatility 


\section{Continued}

\begin{tabular}{|c|c|c|c|c|c|}
\hline Independent Variables & & & & & \\
\hline GDP & $\begin{array}{l}-4.29 \mathrm{e}-11 \\
(2.86 \mathrm{e}-11)\end{array}$ & & & & \\
\hline GDP per capita & $\begin{array}{c}0 \\
\text { (omitted) }\end{array}$ & & & & \\
\hline Unemployment (\%) & $\begin{array}{c}0 \\
\text { (omitted) }\end{array}$ & $\begin{array}{l}2,816,423^{* *} \\
(1,367,568)\end{array}$ & & & \\
\hline Log (Population) & $\begin{array}{c}0 \\
\text { (omitted) }\end{array}$ & & & & \\
\hline Public Debt \% Of GDP & $\begin{array}{c}0 \\
\text { (omitted) }\end{array}$ & & & & \\
\hline Bank Capital to Assets Ratio (\%) & $\begin{array}{c}0 \\
\text { (omitted) }\end{array}$ & & $\begin{array}{l}-438,472^{* *} \\
(1,044,215)\end{array}$ & & \\
\hline Inflation (\%) & $\begin{array}{c}-1,735,981^{* *} \\
(-2.24)\end{array}$ & & & & \\
\hline Economic Freedom & $\begin{array}{c}-3,176,978^{\star * *} \\
(-3.29)\end{array}$ & & & & \\
\hline Interest Rates (Gov Bonds) & $-7,753,608$ & & & $-1949336^{* *}$ & \\
\hline $10 \mathrm{Y}$ & $(1,442,226)$ & & & $(1005638)$ & \\
\hline Freedom from Corruption & $\begin{array}{l}-1,103,397 \\
(5,378,363)\end{array}$ & & & & \\
\hline Fiscal Freedom & $\begin{array}{l}5,534,044 \\
(7,689,659)\end{array}$ & & & & $\begin{array}{l}-743077^{* *} \\
(374613)\end{array}$ \\
\hline Business Freedom & $\begin{array}{l}-1,957,668 \\
(2,168,171)\end{array}$ & & & & \\
\hline Investment Freedom & $\begin{array}{l}-0.6655107 \\
(2,736,405)\end{array}$ & & & & \\
\hline Income Tax Rate (\%) & $\begin{array}{l}3,517,256 \\
(9,821,794)\end{array}$ & & & & \\
\hline Corporate Tax Rate (\%) & $\begin{array}{l}1,314,354 \\
(2,205,902)\end{array}$ & & & & \\
\hline Financial Freedom & $\begin{array}{l}-6,127,787 \\
(1,685,506)\end{array}$ & & & & \\
\hline $\begin{array}{l}\text { Market Capitalization of Listed } \\
\text { Domestic Companies }\end{array}$ & $\begin{array}{l}5.86 \mathrm{e}-12 \\
(5.48 \mathrm{e}-11)\end{array}$ & & & & \\
\hline $\begin{array}{l}\text { S\&P Global Equity Indices } \\
\text { (Annual \% Change) }\end{array}$ & $\begin{array}{l}-0.3950643 \\
(0.3022939)\end{array}$ & & & & \\
\hline
\end{tabular}




\section{Continued}

\begin{tabular}{|c|c|c|c|c|c|c|c|}
\hline \multirow{2}{*}{$\begin{array}{c}\text { Stocks Traded, Turnover Ratio } \\
\text { of Domestic Shares (\%) }\end{array}$} & & $-0.0598586^{* * *}$ & $-6.90 e-13$ & & & & \\
\hline & & $(0.0108215)$ & $(8.29 \mathrm{e}-11)$ & & & & \\
\hline \multirow{2}{*}{ Stocks Traded, Total Value } & $-5.78 \mathrm{e}-12^{\star *}$ & & -0.0669228 & & & & \\
\hline & $(2.57 \mathrm{e}-12)$ & & $(0.4787676)$ & & & & \\
\hline \multirow{2}{*}{1 Period Lag } & $0.0510537^{\star \star}$ & $0.0004341^{\star *}$ & 0.0543677 & $0.7661213^{*}$ & $0.9500853^{\star * *}$ & $0.9537631^{* * *}$ & $0.7929832^{*}$ \\
\hline & $(0.0183087)$ & $(0.0211777)$ & $(0.2947393)$ & $(0.2349361)$ & $(0.1792904)$ & $(0.1393786)$ & $(0.3067227)$ \\
\hline \multirow{2}{*}{ Constant } & $141,611^{* * *}$ & $1,644,235^{*}$ & 0 & $-2.28 \mathrm{e}+07^{* * *}$ & $1,872,171^{*}$ & $2,252,860$ & $4.13 \mathrm{e}+07^{\star * *}$ \\
\hline & $(3.377322)$ & $(4.702344)$ & (omitted) & $(7,011,565)$ & $(7,189,556)$ & $(3,117,190)$ & $(2.39 \mathrm{e}+07)$ \\
\hline
\end{tabular}

Source: author estimations with data from DataStream (2017), World Bank Open Data (2017) and The Heritage Foundation (2012)-(2016). Note: standard errors appear in parenthesis; ${ }^{* *}$ statistically significant at the $1 \%$ level; ${ }^{* *}$ statistically significant at the $5 \%$ level; ${ }^{*}$ statistically significant at the $10 \%$ level.

Table 11. Regression summary dynamic panel data.

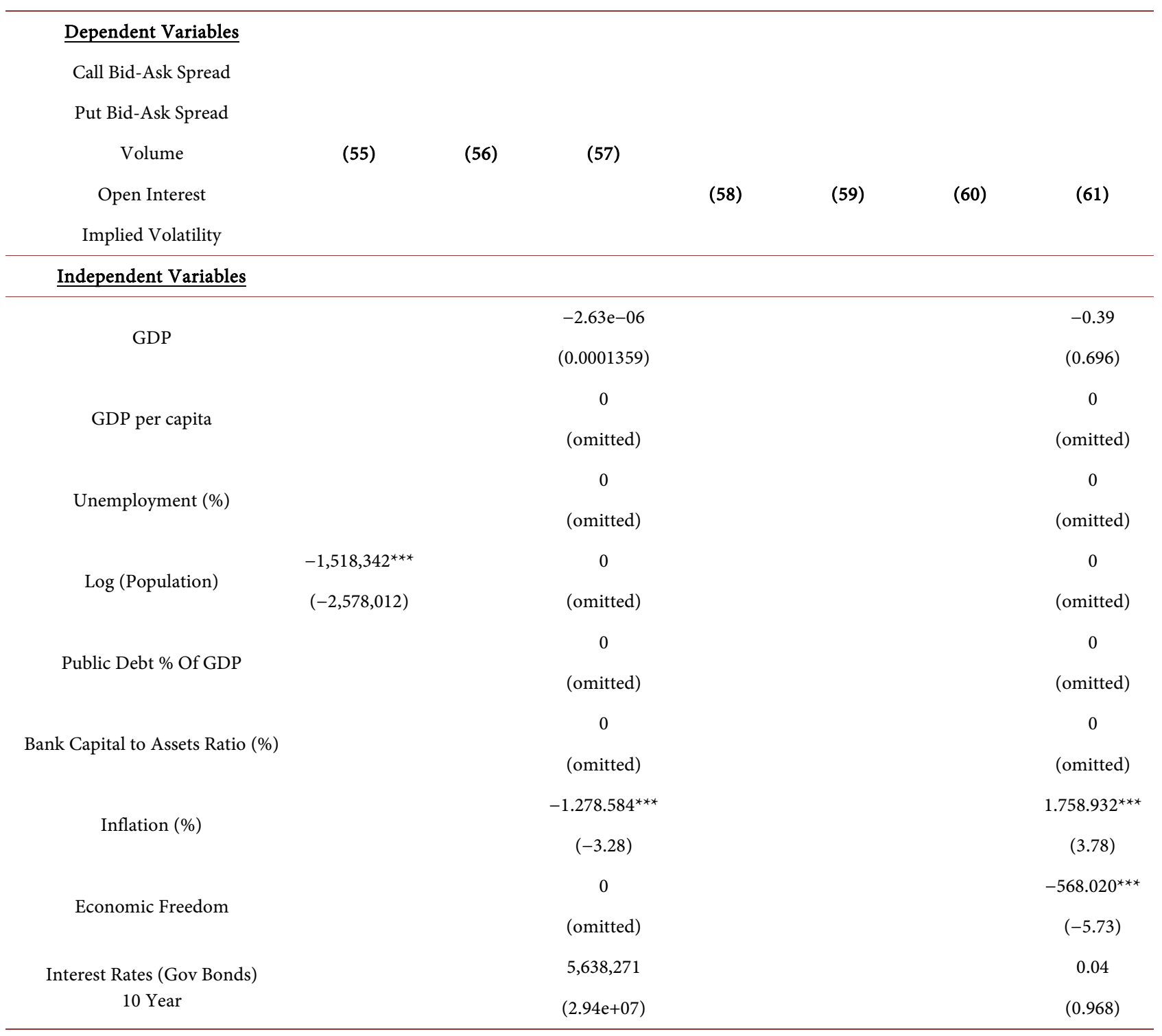




\section{Continued}

\begin{tabular}{|c|c|c|c|c|c|c|c|}
\hline \multirow{2}{*}{ Freedom from Corruption } & & & $214,266.4$ & & & & 0.28 \\
\hline & & & $(1.44 \mathrm{e}+07)$ & & & & $(0.776)$ \\
\hline \multirow[b]{2}{*}{ Fiscal Freedom } & & & $-2,120,027$ & & $-4.59 \mathrm{e}+07^{\star *}$ & & -0.38 \\
\hline & & & $(1.94 \mathrm{e}+07)$ & & $(1.38 \mathrm{e}+07)$ & & $(0.705)$ \\
\hline \multirow{2}{*}{ Business Freedom } & & & $748,265.3$ & & & & 0.22 \\
\hline & & & $(3,402,481)$ & & & & $(0.829)$ \\
\hline \multirow{2}{*}{ Investment Freedom } & & & $351,467.5$ & & & & 0.35 \\
\hline & & & $(5,055,412)$ & & & & $(0.730)$ \\
\hline \multirow{2}{*}{ Income Tax Rate (\%) } & & & 306,584 & & & $6.43 \mathrm{e}+07^{\star \star}$ & -0.27 \\
\hline & & & $(2.71 \mathrm{e}+07)$ & & & $(2.38 \mathrm{e}+07)$ & $(0.785)$ \\
\hline \multirow{2}{*}{ Corporate Tax Rate (\%) } & & & $-677,486.7$ & & & & -0.29 \\
\hline & & & $(5.52 \mathrm{e}+07)$ & & & & $(0.772)$ \\
\hline \multirow{2}{*}{ Financial Freedom } & & & $-191,546.9$ & & & & 0.25 \\
\hline & & & $(4.15 \mathrm{e}+07)$ & & & & $(0.804)$ \\
\hline Market Capitalization of & & $0.0000144^{* *}$ & 0.0000122 & & & & -0.16 \\
\hline Listed Domestic Companies & & $(7.34 \mathrm{e}-06)$ & $(0.0000962)$ & & & & $(0.871)$ \\
\hline \multirow{2}{*}{$\begin{array}{l}\text { S\&P Global Equity Indices } \\
\text { (Annual \% Change) }\end{array}$} & & & $272,695.3$ & & & & 0.40 \\
\hline & & & $(610,587)$ & & & & $(0.690)$ \\
\hline \multirow{2}{*}{$\begin{array}{l}\text { Stocks Traded, Turnover Ratio } \\
\text { of Domestic Shares (\%) }\end{array}$} & & & 0.0000221 & $221,723^{* * *}$ & & & 0.33 \\
\hline & & & $(0.0001919)$ & $(86,706.14)$ & & & $(0.743)$ \\
\hline \multirow{2}{*}{ Stocks Traded, Total Value } & & & $-108,881.7$ & & & & -0.30 \\
\hline & & & $(1,129,226)$ & & & & $(0.766)$ \\
\hline \multirow{2}{*}{1 Period Lag } & $-0.01347^{* *}$ & $1,174,069^{* * *}$ & 117,976 & $0.2308868^{* * *}$ & $0.2960873^{* *}$ & $0.3436831^{\star \star \star}$ & 1.18 \\
\hline & $(0.2103805)$ & $(0.1063797)$ & $(3,783,212)$ & $(0.2245345)$ & $(0.065737)$ & $(0.0679785)$ & $(0.236)$ \\
\hline \multirow{2}{*}{ Constant } & $5.45 \mathrm{e}+08^{* * *}$ & $-1.98 \mathrm{e}+07^{\star *}$ & 0 & $4.40 \mathrm{e}+08^{* *}$ & $2.95 \mathrm{e}+09^{* *}$ & $-2.63 e+09^{*}$ & 0 \\
\hline & $(1.60 \mathrm{e}+08)$ & $(7,585,351)$ & (omitted) & $(3.05 \mathrm{e}+08)$ & $(8.88 \mathrm{e}+08)$ & $(1.12 \mathrm{e}+09)$ & (omitted) \\
\hline
\end{tabular}

Source: author estimations with data from DataStream (2017), World Bank Open Data (2017) and The Heritage Foundation (2012)-(2016). Note: standard errors appear in parenthesis; ${ }^{* *}$ statistically significant at the $1 \%$ level; ${ }^{* *}$ statistically significant at the $5 \%$ level; *statistically significant at the $10 \%$ level.

Table 12. Regression summary dynamic panel data.

\section{$\underline{\text { Dependent Variables }}$}

Call Bid-Ask Spread

Put Bid-Ask Spread

Volume

Open Interest

Implied Volatility

(62)

(63)

(64)

(65)

(66)

(67)

(68)

(69)

(70) 


\section{Continued}

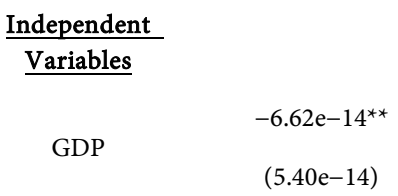

$$
-6.62 \mathrm{e}-14^{* *}
$$

$(5.40 \mathrm{e}-14)$

$-1.84 \mathrm{e}-06^{* *}$

$(6.83 e-07)$

$-0.0070828^{*}$

$(0.0035929)$

$4.59 \mathrm{e}+07^{* *}$

$(1.38 \mathrm{e}+07)$

$0.006112^{* * *}$

(0.001977)

$-0.0195129^{* * *}-0.0195129^{* * *}$

$(0.0036049) \quad(0.0036049)$

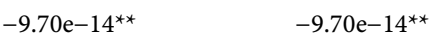

$(4.30 \mathrm{e}-14)$

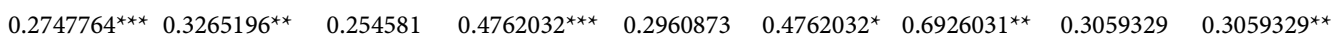

$\begin{array}{lllllllll}(0.1625928) & (0.1503247) & (0.1600788) & (0.1640055) & (0.065737) & (0.1640055) & (0.2127965) & (0.1678321) & (0.1678321)\end{array}$

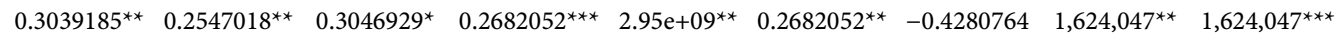

$\begin{array}{llllllllll}(0.108883) & (0.0551108) & (0.0763784) & (0.0676048) & (8.88 \mathrm{e}+08) & (0.0676048) & (0.1717797) & (0.2695451) & (0.2695451)\end{array}$

Source: author estimations with data from DataStream (2017), World Bank Open Data (2017) and The Heritage Foundation (2012)-(2016). Note: standard errors appear in parenthesis; ${ }^{* *}$ statistically significant at the $1 \%$ level; ${ }^{* *}$ statistically significant at the $5 \%$ level; ${ }^{*}$ statistically significant at the $10 \%$ level.

\section{Results}

\subsection{Spread}

The call bid-ask spread is positively correlated with the stocks turnover ratio at all significance levels when the random effects model is used. It is positively correlated with the market capitalization and the GDP at the $1 \%$ level when the dynamic panel data model is employed. Multivariate regressions reveal that the call bid-ask spread is positively correlated with the stock turnover ratio at the 5\% level and with the bank capital to asset ratio at the $10 \%$ level. It is negatively correlated with 10-year government bond yield, the stock turnover ratio, the stock traded value at the 5\% level and with the freedom from corruption at the $10 \%$ level, when the random effects model is used. The call bid-ask spread is positively correlated with the market capitalization and income tax rate at the $1 \%$ level, with the stock turnover ratio at the 5\% level, with the log GDP and with the fiscal freedom at the $10 \%$ level. It is negatively correlated with stock traded value and the freedom from corruption at the 5\% level, with the fixed effects model. The call bid-ask spread is positively correlated with the investment freedom at 
the $1 \%$ level and with the business freedom at the $1 \%$ level. It is negatively correlated with the economic freedom, the 10-year government bond yield and the previous year spread at the $1 \%$ level, when the dynamic panel data model is employed.

Implementing a crossectional data OLS the call bid-ask spread is negatively correlated with the index of economic freedom at the $10 \%$ level, with GDP and stock traded value at the 5\% level and freedom from corruption at all significance levels. It is positively correlated with the public debt as a \% of GDP at the $10 \%$ level; the GDP per capita and the market capitalization at the $5 \%$ level.

The put spread is negatively correlated with the stock turnover ratio at the $1 \%$ level with the use of fixed effects model. It is negatively correlated with the log of public debt to GDP and the stock turnover ratio at the $1 \%$ level, the public debt to GDP and the stock traded total value at the $5 \%$ level, whereas it is positively correlated with the financial freedom at the $1 \%$ level. The put bid-ask spread is positively correlated with the bank capital to asset ratio at the $1 \%$ level. It is negatively correlated with the 10-year government bond yield and the freedom from corruption, at the 5\% level and with the stock traded value and the S\&P global equity index annual change at the $10 \%$ significance level, with the random effects model. The put bid-ask spread is positively correlated with the log GDP, the economic freedom, the fiscal freedom, the income tax rate and the stock turnover ratio at the $1 \%$ level and with the log population at the $5 \%$ level. It is negatively correlated with the freedom from corruption, the business freedom and the stock traded value at the $1 \%$ level, with the S\&P global equity index annual change at the $5 \%$ level, with the fixed effects model. It is positively correlated with the fiscal freedom, the income tax rate, the corporate tax rate and the stock turnover ratio at all significance levels and with the previous year put spread at the $10 \%$ level. It is negatively correlated with the 10 -year government bond yield, the freedom from corruption, the business freedom, the market capitalization, the S\&P global equity index annual change, the financial freedom and the stock traded value at the $1 \%$ level with the dynamic panel data model.

Implementing a crossectional data OLS put bid-ask spread is positively correlated with the public debt as a \% of GDP, the GDP per capita, the stock traded value and the GDP at the 5\% level and the unemployment at all significance levels. It is negatively correlated with index of economic freedom, the market capitalization and the stock turnover ratio at the $5 \%$ level; the property rights, the freedom from corruption at all significance levels, the business freedom at the $10 \%$ level and the financial freedom at the $10 \%$ level.

\subsection{Volume}

The volume is positively correlated with the unemployment rate and the market capitalization at the $5 \%$ level, whereas it is negatively correlated with the population at the $1 \%$ level and the 10 -year government bond yield, the fiscal freedom, the bank capital to asset ratio at the $5 \%$ significance level, with the dynamic pan- 
el univariate model. The volume is positively correlated at the $1 \%$ level with the business freedom at the $1 \%$ level and with the 10 -year government bond yield at the $5 \%$ level. It is negatively correlated with the bank capital to asset ratio at the $1 \%$ level, with the economic freedom and the investment freedom at the $5 \%$ level, with the random effects model. The volume is positively correlated with the economic freedom at the $1 \%$ level, with the market capitalization at the $5 \%$ level. It is negatively correlated with the unemployment rate, the bank capital to asset ratio, the business freedom at the $1 \%$ level, with the financial freedom at the $5 \%$ level, with the fixed effects model. The volume is positively correlated with the inflation, the 10-year government bond yield, the business freedom, the market capitalization, the financial freedom, the income tax rate and the stocks traded value at the $1 \%$ level. It is negatively correlated with the economic freedom, the investment freedom and the population and the previous year volume at the $1 \%$ level when the dynamic panel data model is used.

Implementing a crossectional data OLS, volume is positively correlated at the $1 \%$ level with the GDP and at the 5\% level with the GDP per capita, the stock traded value, the market capitalization and the stock turnover ratio. It is negatively correlated at the $10 \%$ level with the corporate tax rate.

\subsection{Open interest}

The open interest is positively correlated with the income tax rate and the stock turnover ratio at the $1 \%$ level, whereas it is negatively correlated with the fiscal freedom at the $1 \%$ level, with the univariate dynamic panel data model. The open interest is positively correlated with the inflation, the 10 -year government bond yield, the stock traded value at the $10 \%$ level. It is negatively correlated with the stock turnover ratio at the $10 \%$ level with the multivariate random effects model. The open interest is negatively correlated with the financial freedom at the $10 \%$ level, according to the fixed effects model. The open interest is positively correlated with the fiscal freedom, the investment freedom, the income tax rate, the corporate tax rate, the stock traded ratio and the previous year open interest at the $1 \%$ level. It is negatively correlated with inflation, the 10 -year government bond rate, the freedom from corruption, the market capitalization, the stock traded value and the financial freedom at the $1 \%$ level, with the dynamic panel data model.

When implementing a crossectional data OLS open interest is positively correlated at the $1 \%$ level with the GDP, the GDP per capita, the stock traded value and the stock turnover ratio at the 5\% level and the FDI inflows at the $10 \%$ level. It is negatively correlated with the market capitalization at the at $5 \%$ level.

\subsection{Implied Volatility}

The implied volatility is positively correlated with the S\&P global equity index annual change at the $10 \%$ level, with the univariate random effects model. It is negatively correlated with the S\&P global equity index annual change at the $10 \%$ 
level, with the random effects model. It is positively correlated with the investment freedom at the $1 \%$ level. It is negatively correlated with the financial freedom, the corporate tax rate, the business freedom, GDP per capita at the $1 \%$ level; with the market capitalization, the log GDP per capita, the unemployment and the log GDP at the 5\% level, with the dynamic panel data model. The implied volatility is positively correlated with the log population at the $1 \%$ level and negatively correlated with the business freedom at the $5 \%$ level and with the log GDP at the $10 \%$ level, with the multivariate random effects model. The implied volatility is positively correlated with the economic freedom at the $1 \%$ level, with the log population and market capitalization at the $5 \%$ level. It is negatively correlated with the bank capital to asset ratio, the business freedom at the $1 \%$ level, the financial freedom at the $5 \%$ significance level and with the unemployment at the $10 \%$ level, with the fixed effects model. The implied volatility is positively correlated with the market capitalization at the $10 \%$ level, with the dynamic panel data model.

Implementing a crossectional data OLS, the implied volatility is negatively correlated with the GDP, the stock traded value and investment freedom at the 5\% level, the index of economic freedom at the $1 \%$ level, the property rights and the freedom from corruption at the $10 \%$ level. It is positively correlated with the GDP per capita, the market capitalization and the stock traded value at the at $5 \%$ level.

The variables that have been not mentioned for any of the models used show no statistical significance.

\section{Implications}

\subsection{Bid-Ask Spread}

As anticipated the lowest the unemployment, the lowest the income tax rate, the highest the freedom from corruption, the highest the business freedom, the highest the property rights, the lowest the bid-ask spread is, according to most of the models. Furthermore, according to at least one model, the highest the market capitalization, the highest the total value of stock traded, the highest the financial freedom and the highest the economic freedom, the lowest the bid-ask spread is.

\subsection{Volume}

In line with our expectation, the highest business freedom, the market capitalization, the total value of stocks traded and the GDP per capita are and the lowest the tax rate is, the more liquid in terms of volume the option market is, as evidenced by all models. In addition, at least one model indicates that the highest the GDP, the population, the turnover ratio of the stocks traded, the highest the volume of the options traded is.

\subsection{Open Interest}

As anticipated, the highest the GDP, the population, the economic freedom, the 
S\&P global equity index annual change, the total value of the stocks traded, the GDP per capita, the FDI inflows and the lowest the inflation, the 10-year government bond yield, the highest the open interest is, according to most of the models. Moreover, at least one of the models shows that the highest the fiscal freedom and the highest the turnover ratio of the stocks traded, the highest the open interest is.

\subsection{Implied Volatility}

As expected, the lowest the bank capital to assets ratio, the highest the economic freedom, the highest the freedom from corruption, the highest the business freedom, the highest the financial freedom, the lowest the implied volatility is, according to the majority of the models. At least one of the models indicates that the lowest the interest rate, the highest investment freedom, the highest the turnover ratio of the stocks traded, the highest the total value of the stocks traded and the highest the GDP per capita, the lowest the implied volatility is.

According to the above findings, a country that wishes to increase the liquidity of its option market needs to pay attention besides its macroeconomic figures (such as GDP, GDP per capita and unemployment) to the overall equity market capitalization, volume, etc., the level of interest rates (as measured by the 10-year government bond yield) and the bank sector health. It has to contain its corporate tax rate to affordable levels. It needs to improve the economic freedom indices (economic freedom, business freedom, financial freedom, investment freedom and the freedom from corruption). Although such indices reflect perception, it seems that perception is key in attracting investors in the derivatives markets.

\subsection{Policy Implications}

A set of potential directions which an EU country and in particular a distressed country like Greece that has been hit a lot by the crisis, could follow, would be to reduce the unemployment, reinforce the bank capital, improve the perception of the county economic freedom, rationalize the corporate and income tax rates and attract investments so as to increase the overall market capitalization. In addition, it needs to increase the GDP and GDP per capita, but this may be a harder target to achieve and comes along with the global growth target of the country. However, the former indicated directions are probably easier to influence and are desired for other reasons as well. Such reasons could be the overall strengthening of the economy of the country, which will eventually result in the increase of the GDP and finally growth. Consequently, policymakers need to seriously consider revisiting these items, also for the purpose of boosting the derivatives market liquidity, which is crucial for its viability.

The first set of directions can be pursued at an EU level. The European Central Bank has often taken measures to secure the viability of the banking system of its member states, support the common currency (i.e. the Euro) and the 
economies of its member states as whole. Making sure that banks have excess capital reinforces the trust to the banking sector and the financial services globally. Even if (individual) investors do not invest directly in the option markets, it can be the institutional investors among which are banks that can do so. Furthermore, most banks have subsidiary or affiliated investment or brokerage firms or mutual fund management companies; they can thus direct part of the own or affiliated capital to the option markets.

At the same time the EU attempts to create level playing field among its member states and the actors of the financial system independently of their domiciliation through common regulation, legislation and supervision. This can definitely improve the perception of investors on the economic freedom (as reflected by the economic freedom, the business freedom, the financial freedom, the investment freedom and the freedom from corruption) of a country, inspire the trust in the institutions and the authorities of the country and thus attract investments that will increase the market capitalization and thus the liquidity of its option market.

The EU, especially the last decade, since the outburst of the financial crisis, which has been followed by the sovereign crisis and recently with the crisis due to the pandemic, has put at work funds that aim at supporting employment. Besides that it has offered incentives for boosting entrepreneurship (including micro and individual level). It is though up to each member state to fully exploit the dynamic of such a support.

Finally, it is definitely up to each country to set the corporate and income tax at levels that allow for equilibrium between the proceeds sought by the government through direct taxes and the benefits it can have by increased investments and entrepreneurial activity that privileges reduced taxes. Policymakers both at a country and at EU level need to balance the aforementioned determinants in such a way that option markets enjoy the desired liquidity. It is clear that if they act in these directions they will not do so purely for the benefit of the option markets; they will most likely do it for the benefit if the economy, the society and the market as a whole. However, our analysis indicates that as soon as these conditions are in place option market liquidity is anticipated to increase.

\section{Conclusions and Future Reasearch}

The aim of this study was to unveil the macroeconomic determinants of liquidity in option markets, measured-according to the existing literature-by the open interest, the volume (number of transactions), the implied volatility and the bid-ask spread. As all original works it has some limitations; these pertain primarily to the dataset. Namely, the period under investigation is the time interval 2012-2016, being the period immediately following the crisis but also due to data availability. In addition, the frequency of the macroeconomic date was smaller than the frequency of the option data. Nevertheless, it offered interesting results with regards to the determinants of option market liquidity. 
Option market liquidity is sought both by the derivatives exchanges and the investors and its determinants have not been sufficiently researched. The models employed revealed that certain country macroeconomic figures (GDP, GDP per capita and unemployment), the equity market capitalization, the level of interest rates, the bank sector health, the corporate tax rates and the perceived economic freedom (as reflected by the economic freedom, the business freedom, the financial freedom, the investment freedom and the freedom from corruption) influence liquidity. The latter was measured by volume, open interest, bid-ask spread and implied volatility.

These findings can be of use to the respective authorities who are looking for ways to increase the liquidity of the derivatives markets of their responsibility. Evidence was found that such ways could be to reduce the unemployment, reinforce the bank capital, improve the perception of the county economic freedom, rationalize the corporate and income tax rates and attract investments so as to increase the overall market capitalization. Furthermore, it could be to focus on increasing the GDP and the GDP per capita, which however may be harder to achieve.

As the liquidity of option markets is of material interest to the stakeholders, the research performed in this paper can be definitely continued. Future research includes a bigger number of countries, not necessarily limited to Europe. Furthermore, it expands to the use of higher frequency data for the macroeconomic variables, so as to match the frequency of the option data. Access to a broader dataset will allow the identification of potential differences in the liquidity of call and put options. Last but not least, we reckon that moneyness plays a role in the liquidity of options and we would like to study it further by employing at the money option data.

\section{Conflicts of Interest}

The authors declare no conflicts of interest regarding the publication of this paper.

\section{References}

(2013). Regress Time Series-Postestimation Tools for Regress with Time Series. https://www.stata.com/manuals13/rregresspostestimation.pdf

(2013). Regress-Linear Regression. https://www.stata.com/manuals13/rregress.pdf

(2013). Vce Options-Variance Estimators.

https://www.stata.com/manuals13/xtvce_options.pdf

(2013). Xtabond-Arellano-Bond Linear Dynamic Panel-Data Estimation.

https://www.stata.com/manuals13/xtxtabond.pdf\#xtxtabond

(2013). Xtdpd-Linear Dynamic Panel-Data Estimation.

https://www.stata.com/manuals13/xtxtdpd.pdf\#xtxtdpd

(2013). Xtreg-, Fixed-, between-, and Random-Effects and Population-Averaged Linear Models. https://www.stata.com/manuals13/xtxtreg.pdf\#xtxtreg 
Baltagi, B. H. (2013). Econometric Analysis of Panel Data (5th ed., pp. 135-161, 175-180). Wiley.

Bernales, A., Canon, C., \& Verousis, T. (2018). Bid-Ask Spread and Liquidity Searching Behaviour of Informed Investors in Option Markets. Finance Research Letters, 25, 96-102. https://doi.org/10.1016/j.frl.2017.10.025

Bruno, G. S. F. (2005). Estimation and Inference in Dynamic Unbalanced Panel-Data Models with a Small Number of Individuals. The Stata Journal, 5, 473-500. https://doi.org/10.1177/1536867X0500500401

Cao, M., \& Wei, J. (2010). Option Market Liquidity: Commonality and Other Characteristics. Journal of Financial Markets, 13, 20-48.

https://doi.org/10.1016/j.finmar.2009.09.004

Capelle, B. G. (2001). Volatility Trading in Options Market: How Does It Affect Where Informed Traders Trade? Working Paper, EconomiX-Université Paris X Nanterre.

Chaudhury, M. (2015). Option Bid-Ask Spread and Liquidity. The Journal of Trading, 10, 44-56. https://doi.org/10.3905/jot.2015.10.3.044

Cherian, J. A. (1999). Discretionary Volatility Trading in Options Markets. Working Paper, NUS Business School.

Cherian, J. A. (1997). Information Trading, Volatility, and Liquidity in Option Markets. The Journal of Derivatives Winter, 7, 53-65.

Datastream (2017). Thomson Reuters Datastream. Subscription Service.

Demsestz, H. (1968). The Cost of Transacting. The Quarterly Journal of Economics, 82, 33-53. https://doi.org/10.2307/1882244

Donders, M. W. M., Kouwenberg, R., \& Vorst, T. C. F. (2000). Options and Earnings Announcements: An Empirical Study of Volatility, Trading Volume, Open Interest and Liquidity. European Financial Management, 6, 149-171. https://doi.org/10.1111/1468-036X.00118

Gueant, O. (2016). Optimal liquidation with different benchmarks. In The Financial Mathematics of Market Liquidity (pp. 89-114). Chapman and Hall/CRC.

Guéant, O., \& Pu, J. (2017). Option pricing and hedging with execution costs and market impact. Mathematical Finance, 27, 803-831.

Kalodera, I., \& Schlag, C. (2004). An Empirical Analysis of the Relation between Option Market Liquidity and Stock Market Activity. European Financial Management Association, Basel, 30 June-3 July 2004. https://doi.org/10.2139/ssrn.493502 https://papers.ssrn.com/sol3/papers.cfm?abstract_id=493502

Mayhew, S., Sarin, A., \& Shastri, K. (1999). What Drives Option Liquidity? Working Paper, University of Pittsburgh.

Shah, S., \& Brorsen, B. W. (2013). Are Liquidity Costs Higher in Options Markets or in Futures Markets? Applied Financial Economics, 23, 701-708. https://doi.org/10.1080/09603107.2012.750419

Shah, S., Brorsen, B. W., \& Anderson, K. B. (2009). Liquidity Costs in Futures Options Markets. Proceedings of the NCCC-134 Conference on Applied Commodity Pricing Analysis, Forecasting and Market Risk Management, St. Louis, 20-21 April 2009.

TDAmeritrade (2015). Options Liquidity: Why It Matters, Where to Find It, the Ticker Tape. https://tickertape.tdameritrade.com/trading/find-options-liquidity-15225

The Heritage Foundation (2012-2016). Index of Economic Freedom. https://www.heritage.org/index/

Wei, J., \& Zheng, J. (2010). Trading Activity and Bid-Ask Spreads of Individual Equity 
Options. Journal of Banking \& Finance, 34, 2897-2916.

https://doi.org/10.1016/j.jbankfin.2010.02.012

World Bank (2017). World Bank Open Data. https://data.worldbank.org

Battalio, R., \& Schultz, P. (2011). Regulatory Uncertainty and Market Liquidity: The 2008 Short Sale Ban's Impact on Equity Option Markets. The Journal of Finance, 66, 2013-2053.

Cberian, J. A., \& Vila A. F. (1997). Information Trading, Volatility, and Liquidity in Options Markets. The Research Foundation of the Institute of Chartered Financial Analysts-AIMR Publications Series.

https://www.cfainstitute.org/-/media/documents/book/rf-publication/1997/rf-v1997-n 1-4458-pdf 


\section{Appendix}

The form/sign of the correlations observed from regressions on only statistically significant cases are presented. Independent and depended variables that are not included did not establish a statistically significant relationship.

Appendix Table A1. Correlation sign fixed and random effects models.

\begin{tabular}{|c|c|c|c|c|c|c|}
\hline \multirow[b]{2}{*}{ Independent Variables } & \multicolumn{3}{|c|}{ Results of Fixed Effects Model } & \multicolumn{3}{|c|}{ Results of Random Effects Model } \\
\hline & $\begin{array}{l}\text { Effect on Call } \\
\text { and Bid Spread }\end{array}$ & $\begin{array}{c}\text { Effect on } \\
\text { Open Interest }\end{array}$ & $\begin{array}{l}\text { Effect on } \\
\text { Volatility }\end{array}$ & $\begin{array}{c}\text { Effect on Call } \\
\text { and Bid Spread }\end{array}$ & $\begin{array}{l}\text { Effect on } \\
\text { Volume }\end{array}$ & $\begin{array}{l}\text { Effect on } \\
\text { Volatility }\end{array}$ \\
\hline $\log (\mathrm{GDP})$ & + & + & & & & \\
\hline Unemployment (\%) & & & - & & & \\
\hline Log (Population) & + & + & & & & + \\
\hline Bank Capital to Assets Ratio (\%) & & & - & + & - & \\
\hline Economic Freedom & + & + & & & - & \\
\hline Interest Rates (Gov Bonds) 10 Year & & & + & - & & \\
\hline Freedom from Corruption & - & - & & - & & \\
\hline Fiscal Freedom & + & + & + & & & \\
\hline Business Freedom & - & - & - & & + & - \\
\hline Investment Freedom & & & + & & - & \\
\hline Income Tax Rate (\%) & + & + & & & & \\
\hline Corporate Tax Rate (\%) & & & - & & & \\
\hline S\&P Global Equity Indices (Annual \% Change) & - & + & & & & \\
\hline Stocks Traded, Turnover Ratio of Domestic Shares (\%) & $0 /-$ & - & $0 /-$ & $0 /-$ & & \\
\hline Stocks Traded, Total Value & + & + & + & + & & \\
\hline
\end{tabular}

Source: created by the authors from their estimations with data from DataStream (2017). World Bank Open Data (2017) and The Heritage Foundation (2012)-(2016).

Appendix Table A2. Correlation sign dynamic panel data model and crossectional OLS.

\begin{tabular}{|c|c|c|c|c|c|c|c|c|}
\hline \multirow[b]{2}{*}{ Independent Variables } & \multicolumn{4}{|c|}{ Results of Dynamic Panel Data Model } & \multicolumn{4}{|c|}{ Results of Crossectional OLS } \\
\hline & $\begin{array}{l}\text { Effect on } \\
\text { Call and } \\
\text { Bid } \\
\text { Spread }\end{array}$ & $\begin{array}{l}\text { Effect on } \\
\text { Volume }\end{array}$ & $\begin{array}{c}\text { Effect on } \\
\text { Open } \\
\text { Interest }\end{array}$ & $\begin{array}{l}\text { Effect on } \\
\text { Volatility }\end{array}$ & $\begin{array}{c}\text { Effect on } \\
\text { Call and } \\
\text { Bid } \\
\text { Spread }\end{array}$ & $\begin{array}{l}\text { Effect on } \\
\text { Volume }\end{array}$ & $\begin{array}{c}\text { Effect on } \\
\text { Open } \\
\text { Interest }\end{array}$ & $\begin{array}{c}\text { Effect } \\
\text { on } \\
\text { Volatility }\end{array}$ \\
\hline GDP & $0 /+$ & & & - & - & $+/-$ & + & - \\
\hline Unemployment (\%) & & + & & - & + & & & \\
\hline Log (Population) & & - & & $0 /+$ & & + & + & + \\
\hline Bank Capital to Assets Ratio (\%) & & - & & & & & & \\
\hline Inflation (\%) & - & + & - & & & & & \\
\hline Economic Freedom & - & - & & & - & & & - \\
\hline Interest Rates (Gov Bonds)10 Year & - & $-1+$ & - & & & & & \\
\hline Freedom from Corruption & - & & $-1+$ & & - & & & - \\
\hline
\end{tabular}




\begin{tabular}{|c|c|c|c|c|c|c|c|c|}
\hline Fiscal Freedom & + & - & - & & & & & \\
\hline Business Freedom & - & + & & - & - & & & \\
\hline Investment Freedom & & - & + & + & & & & - \\
\hline Income Tax Rate (\%) & & & + & & & & & \\
\hline Corporate Tax Rate (\%) & & & + & - & & - & & \\
\hline Financial Freedom & $+/-$ & & - & - & - & & & \\
\hline Market Capitalization of Listed Domestic Companies & $0 /+/-$ & + & - & & $+/-$ & + & - & + \\
\hline S\&P Global Equity Indices (Annual \% Change) & - & & & & & & & \\
\hline Stocks Traded, Turnover Ratio of Domestic Shares (\%) & $-1+$ & & + & & - & + & + & + \\
\hline Stocks Traded, Total Value & $0 /-$ & $0 /-$ & - & & $+/-$ & + & + & - \\
\hline Public Debt \% Of GDP & - & & & & + & + & + & $+/-$ \\
\hline GDP Per Capita & & & & $0 /-$ & & & & \\
\hline FDI inflows & & & & & & & + & \\
\hline Property rights & & & & & - & & & \\
\hline
\end{tabular}

Source: created by the authors from their estimations with data from DataStream (2017). World Bank Open Data (2017) and The Heritage Foundation (2012)-(2016).

Appendix Table A3. Regression test reference table.

\begin{tabular}{|c|c|c|c|c|c|c|}
\hline $\begin{array}{l}\text { Regression } \\
\text { Number }\end{array}$ & Regression Models & \multicolumn{2}{|c|}{$\begin{array}{l}\text { OLS Assumption } \\
\text { Violations }\end{array}$} & $\begin{array}{c}\text { Testing } \\
\text { Heteroskedasticity }\end{array}$ & $\begin{array}{c}\text { Testing } \\
\text { Autocorrelation }\end{array}$ & $\begin{array}{c}\text { Correcting } \\
\text { Heteroskedasticity and } \\
\text { Autocorrelation }\end{array}$ \\
\hline 1 & Crossectional OLS & Heteroskedasticity & - & Breusch-Pagan Test & - & Robust Standard Errors \\
\hline 2 & Crossectional OLS & Autocorrelation & - & - & $\begin{array}{c}\text { Breusch-Godfrey } \\
\text { Test }\end{array}$ & Robust Standard Errors \\
\hline 3 & Crossectional OLS & Heteroskedasticity & Autocorrelation & Breusch-Pagan Test & - & Robust Standard Errors \\
\hline 5 & Crossectional OLS & Heteroskedasticity & Autocorrelation & Breusch-Pagan Test & - & Robust Standard Errors \\
\hline 9 & Crossectional OLS & Heteroskedasticity & Autocorrelation & Breusch-Pagan Test & - & Robust Standard Errors \\
\hline 13 & Crossectional OLS & Heteroskedasticity & Autocorrelation & Breusch-Pagan Test & - & Robust Standard Errors \\
\hline 14 & Crossectional OLS & Autocorrelation & - & - & $\begin{array}{c}\text { Breusch-Godfrey } \\
\text { Test }\end{array}$ & Robust Standard Errors \\
\hline 16 & Crossectional OLS & Heteroskedasticity & Heteroskedasticity & Breusch-Pagan Test & - & Robust Standard Errors \\
\hline 22 & Crossectional OLS & Heteroskedasticity & Autocorrelation & Breusch-Pagan Test & - & Robust Standard Errors \\
\hline 24 & Crossectional OLS & Heteroskedasticity & Autocorrelation & Breusch-Pagan Test & - & Robust Standard Errors \\
\hline 25 & Crossectional OLS & Heteroskedasticity & Autocorrelation & Breusch-Pagan Test & - & Robust Standard Errors \\
\hline 26 & Crossectional OLS & Autocorrelation & - & - & $\begin{array}{c}\text { Breusch-Godfrey } \\
\text { Test }\end{array}$ & Robust Standard Errors \\
\hline 29 & Fixed Effects & Heteroskedasticity & - & Breusch-Pagan Test & - & $\begin{array}{c}\text { Vector Robust Standard } \\
\text { Errors }\end{array}$ \\
\hline 30 & FixedEffects & Heteroskedasticity & Autocorrelation & Breusch-Pagan Test & Wooldridge's test & $\begin{array}{c}\text { Vector Robust Standard } \\
\text { Errors }\end{array}$ \\
\hline
\end{tabular}




\section{Continued}

\begin{tabular}{|c|c|c|c|c|c|c|}
\hline 32 & FixedEffects & Heteroskedasticity & Autocorrelation & Breusch-Pagan Test & Wooldridge's test & $\begin{array}{c}\text { Vector Robust Standard } \\
\text { Errors }\end{array}$ \\
\hline 37 & RandomEffects & Heteroskedasticity & Autocorrelation & Breusch-Pagan Test & Wooldridge's test & $\begin{array}{c}\text { Vector Robust Standard } \\
\text { Errors }\end{array}$ \\
\hline 38 & RandomEffects & Autocorrelation & - & - & Wooldridge's test & $\begin{array}{c}\text { Vector Robust Standard } \\
\text { Errors }\end{array}$ \\
\hline 39 & RandomEffects & Autocorrelation & - & - & Wooldridge's test & $\begin{array}{c}\text { Vector Robust Standard } \\
\text { Errors }\end{array}$ \\
\hline 40 & RandomEffects & Autocorrelation & - & - & Wooldridge's test & $\begin{array}{c}\text { Vector Robust Standard } \\
\text { Errors }\end{array}$ \\
\hline 41 & RandomEffects & Heteroskedasticity & - & Breusch-Pagan Test & - & $\begin{array}{c}\text { Vector Robust Standard } \\
\text { Errors }\end{array}$ \\
\hline 42 & DynamicPanelData & Heteroskedasticity & - & Breusch-Pagan Test & - & $\begin{array}{c}\text { Vector Robust Standard } \\
\text { Errors }\end{array}$ \\
\hline 44 & DynamicPanelData & Autocorrelation & - & - & Wooldridge's test & $\begin{array}{c}\text { Vector Robust Standard } \\
\text { Errors }\end{array}$ \\
\hline 45 & DynamicPanelData & Heteroskedasticity & Autocorrelation & Breusch-Pagan Test & Wooldridge's test & $\begin{array}{c}\text { Vector Robust Standard } \\
\text { Errors }\end{array}$ \\
\hline 47 & DynamicPanelData & Heteroskedasticity & Autocorrelation & Breusch-Pagan Test & Wooldridge's test & $\begin{array}{c}\text { Vector Robust Standard } \\
\text { Errors }\end{array}$ \\
\hline 48 & DynamicPanelData & Heteroskedasticity & - & Breusch-Pagan Test & - & $\begin{array}{c}\text { Vector Robust Standard } \\
\text { Errors }\end{array}$ \\
\hline 49 & DynamicPanelData & Heteroskedasticity & Autocorrelation & Breusch-Pagan Test & Wooldridge's test & $\begin{array}{c}\text { Vector Robust Standard } \\
\text { Errors }\end{array}$ \\
\hline 50 & DynamicPanelData & Heteroskedasticity & Autocorrelation & Breusch-Pagan Test & Wooldridge's test & $\begin{array}{c}\text { Vector Robust Standard } \\
\text { Errors }\end{array}$ \\
\hline 51 & DynamicPanelData & Heteroskedasticity & Autocorrelation & Breusch-Pagan Test & Wooldridge's test & $\begin{array}{c}\text { Vector Robust Standard } \\
\text { Errors }\end{array}$ \\
\hline 56 & DynamicPanelData & Heteroskedasticity & Autocorrelation & Breusch-Pagan Test & Wooldridge's test & $\begin{array}{c}\text { Vector Robust Standard } \\
\text { Errors }\end{array}$ \\
\hline 57 & DynamicPanelData & Heteroskedasticity & Autocorrelation & Breusch-Pagan Test & Wooldridge's test & $\begin{array}{c}\text { Vector Robust Standard } \\
\text { Errors }\end{array}$ \\
\hline 58 & DynamicPanelData & Autocorrelation & - & - & Wooldridge's test & $\begin{array}{c}\text { Vector Robust Standard } \\
\text { Errors }\end{array}$ \\
\hline 61 & DynamicPanelData & Autocorrelation & - & - & Wooldridge's test & $\begin{array}{c}\text { Vector Robust Standard } \\
\text { Errors }\end{array}$ \\
\hline 62 & DynamicPanelData & Heteroskedasticity & Autocorrelation & Breusch-Pagan Test & Wooldridge's test & $\begin{array}{c}\text { Vector Robust Standard } \\
\text { Errors }\end{array}$ \\
\hline 63 & DynamicPanelData & Heteroskedasticity & - & Breusch-Pagan Test & - & $\begin{array}{c}\text { Vector Robust Standard } \\
\text { Errors }\end{array}$ \\
\hline 64 & DynamicPanelData & Heteroskedasticity & - & Breusch-Pagan Test & - & $\begin{array}{c}\text { Vector Robust Standard } \\
\text { Errors }\end{array}$ \\
\hline 65 & DynamicPanelData & Heteroskedasticity & Autocorrelation & Breusch-Pagan Test & Wooldridge's test & $\begin{array}{c}\text { Vector Robust Standard } \\
\text { Errors }\end{array}$ \\
\hline 68 & DynamicPanelData & Autocorrelation & - & - & Wooldridge's test & $\begin{array}{c}\text { Vector Robust Standard } \\
\text { Errors }\end{array}$ \\
\hline
\end{tabular}




\section{Continued}

\begin{tabular}{|c|c|c|c|c|}
\hline 69 & DynamicPanelData Heteroskedasticity & - & Breusch-Pagan Test & $\begin{array}{c}\text { Vector Robust Standard } \\
\text { Errors }\end{array}$ \\
\hline 70 & DynamicPanelData Heteroskedasticity & - & Breusch-Pagan Test & $\begin{array}{c}\text { Vector Robust Standard } \\
\text { Errors }\end{array}$ \\
\hline
\end{tabular}

Source: created by the authors from their estimations with data from DataStream (2017). World Bank Open Data (2017) and The Heritage Foundation (2012)-(2016). 